\title{
Zooplankton and Micronekton Active Flux Across the Tropical and Subtropical Atlantic Ocean
}

\begin{abstract}
Santiago Hernández-León ${ }^{1 *}$, María Pilar Olivar², María Luz Fernández de Puelles ${ }^{3}$, Antonio Bode ${ }^{4}$, Arturo Castellón ${ }^{5}$, Cristina López-Pérez ${ }^{2}$, Víctor M. Tuset ${ }^{2}$ and José Ignacio González-Gordillo 6

1 Instituto de Oceanografía y Cambio Global, IOCAG, Universidad de Las Palmas de Gran Canaria, Unidad Asociada ULPGC-CSIC, Canary Islands, Spain, ${ }^{2}$ CSIC, Institut de Ciències del Mar, Barcelona, Spain, ${ }^{3}$ Centro de Baleares, Instituto Español de Oceanografia, Palma, Spain, ${ }^{4}$ Centro Oceanográfico de A Coruña, Instituto Español de Oceanografia, A Coruña, Spain, ${ }^{5}$ CSIC, Unidad de Tecnología Marina, Barcelona, Spain, ${ }^{6}$ Instituto Universitario de Investigación Marina, Universidad de Cádiz, Cádiz, Spain
\end{abstract}

Quantification of the actual amount of carbon export to the mesopelagic layer by both zooplankton and micronekton is at present a gap in the knowledge of the biological pump. These organisms perform diel vertical migrations exporting carbon through respiration, excretion, mortality, and egestion during their residence at depth. The role of zooplankton in active flux is nowadays partially assessed. However, micronekton active flux is scarcely known and only a few studies addressed this downward transport. Even less is known about the capacity of both communities to export carbon in the ocean. Here, we show the results of zooplankton and micronekton active flux across a productivity gradient in the tropical and subtropical Atlantic Ocean. Biomass vertical distribution from the surface up to $800 \mathrm{~m}$ depth by day and night was studied during April 2015 in a transect from $9^{\circ} \mathrm{S}$ to $25^{\circ} \mathrm{N}$, covering from the quite oligotrophic zone off Brazil to the meso- and eutrophic areas of the equator, Guinea Dome, and the oceanic upwelling off Northwest Africa. Zooplankton and micronekton migrant biomass was estimated from day and night catches at different layers of the water column using MOCNESS-1 ( $1 \mathrm{~m}^{2}$ mouth area) and Mesopelagos $\left(35 \mathrm{~m}^{2}\right)$ nets, respectively. Respiratory flux was assessed by measuring the enzymatic activity of the electron transfer system (ETS) of organisms at depth. Results showed a close relationship between migrant biomass and respiratory flux in zooplankton and micronekton as expected. Using a rather conservative 50\% of efficiency for the net used to capture micronekton, respiratory flux resulted in similar values for both communities. Gravitational (passive) flux measured using sediment traps increased from the oligotrophic toward the meso- and eutrophic zones. Total active flux (including respiration and estimated mortality, excretion, and gut flux) by zooplankton and micronekton accounted for about $25 \%$ of total flux (passive plus active) in oligotrophic zones. Total active flux also increased toward meso- and eutrophic zones, reaching about $80 \%$ of total flux and being at least twofold higher than passive flux. These results alert about an important underestimation of the ocean biological pump using only passive flux measurements.

Keywords: biological pump, passive flux, active flux, zooplankton, micronekton, Atlantic Ocean 


\section{INTRODUCTION}

The biological carbon pump exports organic matter from the euphotic to the mesopelagic zone through diverse mechanisms. Sinking particles and the active transport by diel vertical migrants are two main processes, jointly with physical mixing of particulate and dissolved organic matter (Buesseler et al., 2007). Passive or gravitational flux due to particulate organic carbon (POC) sinking is, by far, the most studied mechanism (see Honjo et al., 2008; Guidi et al., 2015). However, active flux, the transport of organic matter performed by organisms due to feeding at night in the epipelagic layer and their egestion (Angel, 1989), metabolism (Longhurst et al., 1990), and mortality (Zhang and Dam, 1997) during their daylight permanence at depth remains partially unknown. More than two decades of research provided a relatively important data set about zooplankton active flux. However, modeling the biological pump is still a challenge due to (1) the limited knowledge of downward transport in different areas of the ocean, and (2) the almost nescience about the actual amount of carbon transported by micronektonic organisms. The latter mechanism is, at present, an important gap in our assessment of the biological pump.

Diel vertical migrants are organisms showing a high diversity and a wide size spectrum. They spread from relatively small crustaceans, mainly large copepods and euphausiids, to micronektonic forms such as fishes (mainly myctophids), large crustaceans (mainly decapods), and cephalopods. This wide spectrum entails serious difficulties for the study of the importance of these organisms in the carbon pump. The use of different types of nets of different meshes and sizes, and depth stratified sampling covering most of the mesopelagic zone are time-consuming ship operations in standard oceanographic cruises. Moreover, expertise in a rather complex taxonomy from zooplankton to micronekton is also needed. Thus, the study of these migrants becomes a rather arduous and expensive subject to obtain a complete picture of the biological pump.

Zooplankton is known to perform diel vertical migrations transporting a significant fraction of organic matter to deep waters (Longhurst et al., 1990). The amount of carbon transported based on respiration at depth (respiratory flux) is somehow related to primary productivity as the biomass of the vertical migrant community is larger in meso- and eutrophic areas of the ocean (Yebra et al., 2018; Hernández-León et al., $2019 b)$. This active flux is quite variable and accounts for less than 4\% (Le Borgne and Rodier, 1997) to more than 100\% (Yebra et al., 2018) of the POC flux. Micronekton active flux is poorly known simply because its study requires large nets which are not a standard in oceanographic cruises. In fact, there are only a handful of works studying their role in transporting carbon downward, most of them on single groups of organisms such as fishes (Hopkins et al., 1996; Davison et al., 2013; Hudson et al., 2014) or decapods (Schukat et al., 2013; Pakhomov et al., 2018). Assessment of active flux by both zooplankton and micronekton are, to our knowledge, limited to two studies (Hidaka et al., 2001; Ariza et al., 2015). Only respiratory fluxes in those studies ranged from 14 to $55 \%$ of the POC flux. Although the latter range is based in only two studies, they suggest that total active flux (considering mortality, excretion, and gut flux) in relation to POC flux by both communities (zooplankton and micronekton) could be significant, and sometimes larger than particle sinking rates (see Yebra et al., 2018).

In this sense, besides the magnitude of the migrant biomass, community structure of pelagic communities also change with productivity. For instance, large organisms increase in areas characterized by abundant resources for feeding (Frost, 1974). Thus, migrant biomass and, therefore, active flux should also change in different productive regimes. Moreover, some populations of large zooplankton could perform seasonal migrations, accumulating lipids in the epipelagic zone and respiring them at depth, promoting the so-called lipid pump (Jónasdóttir et al., 2015). Thus, our knowledge of total active flux and their sources of variability are still quite limited.

In order to study the natural variability of active flux by zooplankton and micronekton in the ocean, we performed a transect of stations from the quite oligotrophic waters off Brazil to the meso- and eutrophic waters off the Northwest African upwelling. The goal of the study was to estimate active flux by both communities in a gradient of productivity at the basin scale from subtropical to equatorial and tropical Atlantic Ocean. We performed vertical profiles of zooplankton and micronekton during day and by night in order to study their vertical migrations, to assess migrant biomass, and to measure the enzymatic activity of the electron transfer system (ETS) as a proxy for respiration rates of these organisms in the water column. Respiratory flux was estimated in both zooplankton and micronekton as a basis to assess total active flux in tropical and subtropical ecosystems.

\section{MATERIALS AND METHODS}

Sampling took place during the "Migrants and Active Flux In the Atlantic ocean" (MAFIA) cruise on board the R. V. "Hespérides" along the tropical and subtropical Atlantic Ocean. We sailed from Salvador de Bahía (Brazil) to the Canary Islands (Spain) from March 31st to April 29th, 2015 (Figure 1). Vertical profiles of temperature, conductivity, oxygen, fluorescence, and pressure were obtained using a CTD (Seabird 911 plus) mounted on a rosette sampler equipped with 121 Niskin bottles. Fluorescence obtained in vertical profiles $(0-200 \mathrm{~m})$ was converted to chlorophyll using samples at discrete depths for calibration. Chlorophyll $a$ was measured filtering $500 \mathrm{ml}$ of Niskin water samples through a $25 \mathrm{~mm}$ Whatman GF/F filter and freezing it at $-20^{\circ} \mathrm{C}$ until their analysis in the laboratory. We extracted pigments by placing the filter in $90 \%$ acetone at $-20^{\circ} \mathrm{C}$ in the dark during $24 \mathrm{~h}$. They were measured on a Turner Design 10A Fluorometer, previously calibrated with pure Chl $a$ (Yentsch and Menzel, 1963), and measured following the acidification method by Strickland and Parsons (1972). Temperature, salinity, oxygen, and chlorophyll sections were represented using Ocean Data View and the DIVA gridding procedure (Schlitzer, 2016).

Passive flux was measured at $150 \mathrm{~m}$ depth using a freedrifting multi-trap array having eight cylinders following the model described by Knauer et al. (1979) using the procedure 


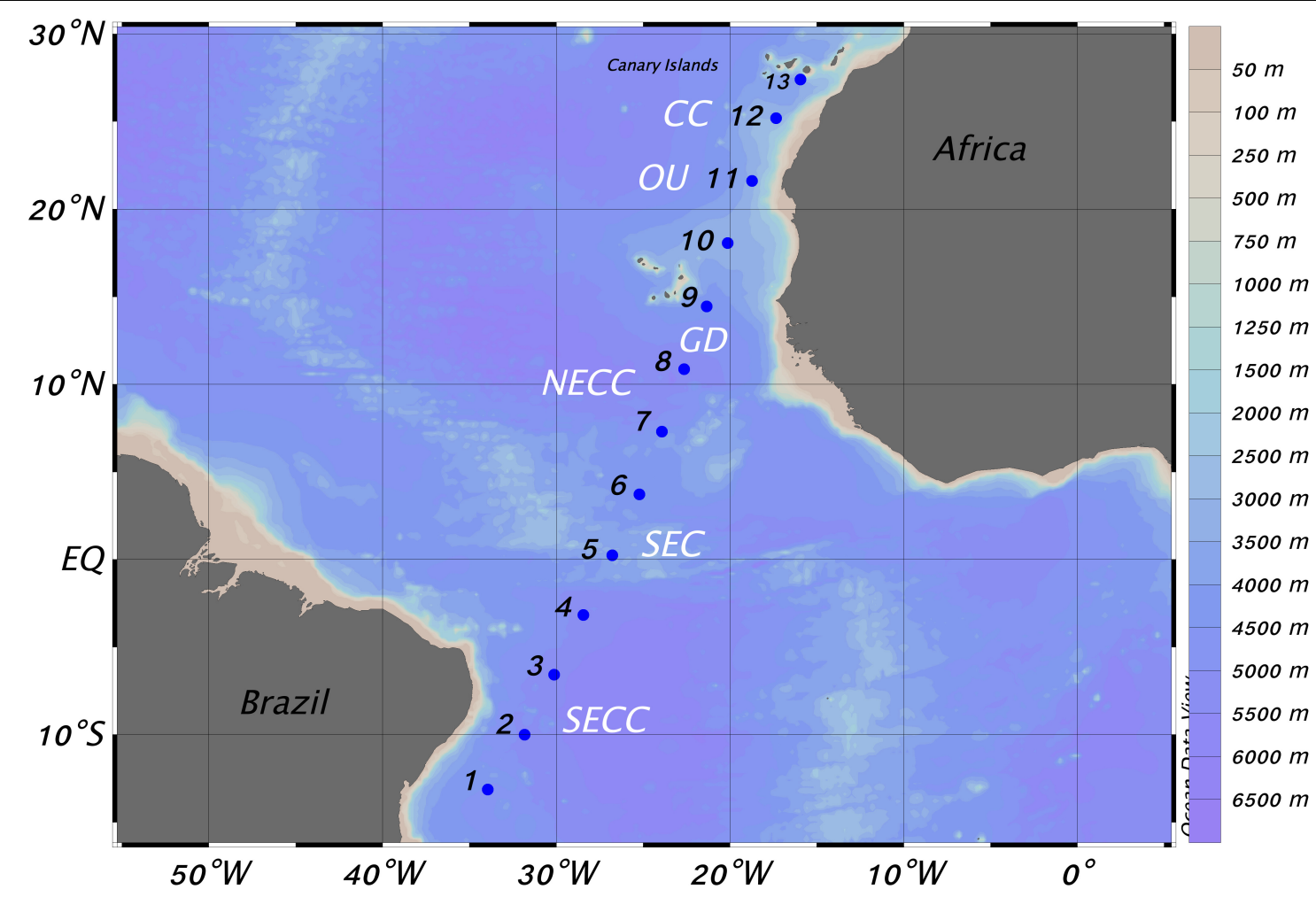

FIGURE 1 | Location of stations carried out in the tropical and subtropical Atlantic Ocean during the Mafia Cruise. CC, Canary Current; OU, Oceanic Upwelling; GD, Guinea Dome; NECC, North Equatorial Counter Current; SEC, South Equatorial Current; SECC, South Equatorial Counter Current (see text).

described in Hernández-León et al. (2019b). In short, the trap was deployed during approximately $24 \mathrm{~h}$ with cylinders containing filtered seawater and a high salinity $\left(\sim 45 \mathrm{~g} \cdot \mathrm{l}^{-1}\right.$ $\mathrm{NaCl}$ analytical reagent grade) to increase density. No poisons were added to retard bacterial decomposition. After recovering, swimmers (different zooplanktonic organisms, mainly copepods) were removed and samples were filtered onto pre-combusted $\left(450^{\circ} \mathrm{C}\right.$ for $\left.12 \mathrm{~h}\right) 25 \mathrm{~mm}$ Whatman GF/F filters. They were frozen at $-20^{\circ} \mathrm{C}$ until analysis in a Carlo Erba CHNSO 1108 elemental analyzer (UNESCO, 1994).

Zooplankton samples were obtained using a MOCNESS-1 net with a $1 \mathrm{~m}^{2}$ mouth opening area, fitted with $200 \mu \mathrm{m}$ mesh size (Wiebe et al., 1976). Oblique hauls were made at about 1.5-2.5 knots during day and night from stations 2 to 12 (Figure 1), and from $800 \mathrm{~m}$ depth to the surface in eight strata: 800-600, 600-500, 500-400, 400-300, 300-200 m, the lower thermocline layer $(200 \mathrm{~m}$ - ca. $100 \mathrm{~m}$ ), the upper thermocline layer (ca. 100-50 m), and the upper mixed layer (ca. 50-0 m) (see Olivar et al., 2018b). Immediately after sampling, organisms were gently collected and samples for enzymatic measurements were picked up, frozen in liquid nitrogen $\left(-196^{\circ} \mathrm{C}\right)$, and later preserved at $-80^{\circ} \mathrm{C}$. After this, the entire sample was preserved in $5 \%$ buffered formalin and seawater. On board, a subsample from each layer was stained using Rose Bengal and later photographed using a Nikon D800 digital camera (36 MP) using a macro lens (MicroNikkor $600 \mathrm{~mm} \mathrm{f/2.8G} \mathrm{ED)} \mathrm{over} \mathrm{a} \mathrm{white} \mathrm{LED} \mathrm{backlight.}$ Images were taken at $1850 \mathrm{dpi}$ resolution and later processed using ZooImage1 according to Grosjean and Denis (2007). Organisms were classified in six groups (copepods, chaetognaths, euphausid-like, gelatinous, other zooplankton, and particleslike). Body area was converted to biomass in terms of dry weight using the empirical relationships given by Hernández-León and Montero (2006), and improved by Lehette and Hernández-León (2009) for the different organisms. Dry weight was converted to carbon units assuming that carbon is $40 \%$ of dry weight (Dam and Peterson, 1993).

Micronekton samples were obtained using a Mesopelagos midwater trawl (Meillat, 2012) with an average mouth opening of $35 \mathrm{~m}^{2}$ and a total length of $50 \mathrm{~m}$. Mesh opening changed from $30 \mathrm{~mm}$ at the mouth to $4 \mathrm{~mm}$ at the end where a multi-sampler, able to collect samples in five different layers, was installed. Details of the system are given elsewhere (Olivar et al., 2017). Hauls were made at about 2-3 knots during day and night from $800 \mathrm{~m}$ to the surface in five consecutive layers (800-700, 700-400, 400-200, 200-100, and 100-0 m) except for station 1 which was restricted to the upper $150 \mathrm{~m}$ depth. The multi-sampler failed to obtain samples in areas or strata with abundant large gelatinous zooplankton or sargassum-weeds, so some stations were not considered for active flux. On board, organisms were sorted and classified to, at least, the family taxa, and wet weight $(\mathrm{Ww})$ measured using a marine precision balance POLS S-182 P-15 (precision $2 \mathrm{~g}$ ). Thereafter, samples were frozen for later species identification and dry weight measurements in the laboratory. Selected species of fishes and decapods were also 
frozen in liquid nitrogen and stored at $-80^{\circ} \mathrm{C}$ for later ETS activity analysis. Leptocephali, relatively abundant at night in the upper surface layer of station 6 , were removed from the migratory organisms as their residence depth during day expanded from surface to ca. $300 \mathrm{~m}$ (Castonguay and McCleave, 1987; Olivar et al., 2018b). Wet weight of fishes were converted to dry weight (Dw) using the $\mathrm{Dw} / \mathrm{Ww}$ ratio of 0.23 obtained for the cruise specimens (López-Pérez, unpublished), similar to the ratios given by Childress and Nygaard (1973). The ratio used for crustaceans was the one given by Pakhomov et al. (2018) of 0.179. Carbon biomass was obtained assuming that it was $40 \%$ of dry weight (Bailey et al., 1995; Lindsay, 2003; and mean value obtained from 79 individuals examined in an earlier study on stable isotope analyses by Olivar et al., 2018a).

Frozen samples were homogenized at the laboratory in a Teflon pestle at $0-4^{\circ} \mathrm{C}$ to avoid degradation of enzyme activity and proteins. ETS activity was measured following the method of Packard (1971) modified by Owens and King (1975), Kenner and Ahmed (1975), and Gómez et al. (1996). Samples were homogenized and centrifuged thereafter at $4000 \mathrm{rpm}$ at $0^{\circ} \mathrm{C}$ for $10 \mathrm{~min}$. An aliquot was subsampled from the homogenate and incubated at $16^{\circ} \mathrm{C}$ for zooplankton and $18^{\circ} \mathrm{C}$ for micronekton, and darkness using $\mathrm{NADH}, \mathrm{NADPH}$, succinate, and a tetrazolium salt (INT) as the artificial electron acceptor. After $20 \mathrm{~min}$, the incubation was stopped with a quench solution. The ETS activity was estimated spectrophotometrically at $490 \mathrm{~nm}$ with a turbidity baseline of $750 \mathrm{~nm}$. In order to correct ETS activity for in situ temperature, we used the Arrhenius equation and an activation energy of $15 \mathrm{kcal} \cdot \mathrm{mol}^{-1}$ (Packard et al., 1975). Protein content was determined using the method of Lowry et al. (1951) modified by Rutter (1967), and using bovine serum albumin (BSA) as the standard. Zooplankton protein content was converted to dry weight using the ratio of 2.49 recently given by Hernández-León et al. (2019a) for zooplankton in subtropical waters. This ratio was also used to convert ETS activity and respiration rates data from previous estimates of respiratory flux in subtropical waters (Hernández-León et al., $2019 b)$ and then compared to the results of the present study. ETS activity in micronekton was measured in the whole animal. Organisms were homogenized and a sub-sample taken for the ETS assay. We converted wet weight (Ww) to dry weight using the above mentioned ratio, and into protein (Prot) using the average Dw/Prot ratios given by Bailey et al. (1995) of 2.21 for fishes, and 2.48 for crustaceans.

Night minus day of integrated biomass profiles in the upper $200 \mathrm{~m}$ layer were used as an estimate of the zooplankton and micronekton migrant biomass. Cephalopods were excluded from our estimations as they did not showed a significant biomass, probably due to escapement. Migrant biomass values were converted to carbon units as shown above. For zooplankton we assumed no net avoidance. However, night minus day biomass for micronekton was estimated for two different capture efficiencies of the net (20 and 50\%). No data about Mesopelagos trawl efficiency is, to our knowledge, available. This is an important shortcoming of our research as it is known that mesopelagic fish biomass in the ocean could be an order of magnitude higher than fishes captured using trawls due to their poor capture efficiency (Koslow et al., 1997; Kloser et al., 2009; Yasuma and Yamamura, 2010; Kaartvedt et al., 2012). Based on comparison between acoustics and net sampling, estimations of catchability for large mid-water trawls normally vary between 6 and 13\% (Gjøsaeter, 1984; May and Blaber, 1989). Koslow et al. (1997) found a similar value of $14 \%$ using a Young Gadoic Pelagic Trawl (YGPT, opening mouth of $105 \mathrm{~m}^{2}$ ). Nets such as MOHT trawl (5 $\mathrm{m}^{2}$, Oozeki et al., 2004) showed capture efficiencies of $14 \%$ for gas-bearing organisms (e.g., mesopelagic fishes), and 38\% for large non-gas-bearing (e.g., decapods) fauna (Davison, 2011). Similarly, a $33.3 \%$ catch efficiency was estimated for the $10 \mathrm{~m}^{2}$ MOCNESS net by Pakhomov et al. (2018). Thus, we assumed the Mesopelagos trawl to catch between 20 and 50\% of the biomass of fishes and crustaceans, and therefore, we estimated biomass using a quite conservative capture efficiency of $50 \%$. In any case, values for an efficiency of $20 \%$ are also provided for comparison.

Respiratory flux in zooplankton was determined using the average ETS activity (in $\mu \mathrm{IO}_{2} \cdot \mathrm{mg}$ protein ${ }^{-1} \cdot \mathrm{h}^{-1}$ ) in the 200$800 \mathrm{~m}$ layer (considered as the residence depth of migrants), and multiplied by the migrant biomass obtained in the epipelagic layer. In micronekton, respiratory flux was determined for fishes and crustaceans using the average ETS activity (in $\mu \mathrm{lO}_{2} \cdot \mathrm{mg}$ protein $^{-1} \cdot \mathrm{h}^{-1}$ ) for myctophids and decapods obtained during the survey, assuming an activation energy of $15 \mathrm{kcal} \cdot \mathrm{mol}^{-1}$ (Packard et al., 1975) and correcting for the average temperature in the 200-800 m layer. A quite conservative respiration to ETS (R/ETS) ratio of 0.5 was used as in zooplankton this ratio normally varies between 0.5 and 1 , mainly depending on the food availability to organisms (see Hernández-León and Gómez, 1996). A residence time at depth of $12 \mathrm{~h}$ was also assumed for both communities. To convert respiration into carbon units, a respiratory quotient $\left(\mathrm{CO}_{2}\right.$ respired $/ \mathrm{O}_{2}$ consumed) of 0.97 (Omori and Ikeda, 1984) was used.

Respiratory flux is only a component of active flux as mortality, excretion, and gut flux should also be considered. In these sense and in order to compare these conservative estimates of active flux with POC flux, we assessed total active flux by zooplankton and micronekton derived from respiratory flux. In zooplankton, mortality was estimated from growth assuming steady-state conditions in the mesopelagic zone (growth = mortality) using the equation of Ikeda and Motoda (1978) relating respiration and growth, and assuming gross growth (growth/ingestion) and assimilation efficiencies of 30 and 70\%, respectively (see review in Omori and Ikeda, 1984). Excretion was assessed using the values of Steinberg et al. (2000) making up $24 \%$ of the respired plus excreted carbon. Gut flux was no added in the total zooplankton active flux assessment as gut passage time in zooplankton is short $(<1 \mathrm{~h}$, Dam and Peterson, 1988), and we assume that fecal pellets are released in the epipelagic zone, and thus, included in the sediment trap data. We are aware that this is not completely true as large copepods and euphausiids have longer gut passage times. However, because of the uncertainty in this transport and in order to be conservative in our estimations we did not add this flux.

Active flux by micronekton including mortality, excretion, and gut flux was also obtained from respiratory flux. Mortality was estimated from growth assuming steady-state conditions, 
and using the growth/metabolism ratio of 0.66 given by Brett and Groves (1979). Excretion was estimated as in zooplankton (see above), gut flux assuming that carnivorous organisms egest an amount equivalent to the $40 \%$ of the respired carbon (Brett and Groves, 1979), and they transport feces to the mesopelagic because of their density and the long gut passage time of large animals. Thus, we used an egestion equivalent to $80 \%$ of the respired carbon as in Ariza et al. (2015) because of their residence at depth and their long gut passage time. Because of this, micronektonic migrants should egest after the downward migration. Thus, the egestion should be double in relation to respiration during $24 \mathrm{~h}$. We are also aware that carbon egestion by marine fishes is also higher because they also release carbonate precipitates as a by-product of osmoregulation (see Wilson et al., 2009). In order to be also conservative in our estimations we did not consider this carbon egestion.

Primary production was obtained from remote sensing data following Behrenfeld and Falkowski (1997) through the Ocean Productivity web site ${ }^{1}$ for the specific dates of the cruise and using the Vertical Generalized Production Model (VGPM). Values were averaged every $0.5^{\circ}$ of longitude around the stations in order to account for the strong variability in the very productive upwelling zones, and because of the comparatively low turnover of zooplankton and micronekton.

\section{RESULTS}

\section{Hydrography and Productivity}

The section carried out covered the tropical and subtropical Atlantic Ocean from the very oligotrophic, high stratified waters off Brazil (Figure 2A) to the meso- and eutrophic waters off the Northwest African upwelling. Descriptions of the physical scenario were published elsewhere (Olivar et al., 2017; Armengol et al., 2019). In short, we moved from the South Equatorial Counter Current (SECC, stations 1-3) observing there a deep thermocline and high salinity (Figure 2B). Stations 46 were located in the South Equatorial Current (SEC) and the Intertropical Convergence Zone (ITCZ). The mid-ocean upwelling was close to station 6 and the North Equatorial Current (NEC) was near station 8. The Oxygen Minimum Zone (OMZ, Figure 2C) expanded from the south to stations 8 and 9, coinciding with the Guinea Dome, where the minimum dissolved oxygen values were observed. Northern stations were marked by the oceanic upwelling off Cape Blanc (Northwest Africa) except station 12 which was performed in the oceanic waters of the Canary Current.

As expected, we found a sharp chlorophyll gradient from the southern stations to the north, showing a deep chlorophyll maximum (DCM) related to the thermocline, and being shallower northward (Figure 2D). Chlorophyll $a$ concentration at the DCM also increased northward and displayed higher values at those stations where the thermocline was shallower (Figure 3A). POC flux showed low values increasing northward in areas of high primary production (Figure 3B). Higher POC fluxes were

\footnotetext{
${ }^{1}$ http://www.science.oregonstate.edu/ocean.productivity/index.php
}

observed in the Guinea Dome and in the oceanic upwelling off Cape Blanc. Primary production sharply increased north of the Guinea Dome and remained high through the oceanic upwelling off Cape Blanc, decreasing in the Canary Current (Figure 3B).

\section{Zooplankton and Micronekton Biomass}

Vertical profiles of zooplankton biomass were obtained from stations 2 to 12 during day and night (Figure 4). The gradient of productivity observed in fluorescence, chlorophyll $a$, and primary production was also observed in the zooplankton biomass, displaying quite low values in the SECC and SEC but increasing northward of the ITCZ (station 7). Zooplankton biomass was always higher at night in the epipelagic zone as the consequence of the diel vertical migration. Largest values of zooplankton migrant biomass were found in station 8 related to the Guinea Dome and in the oceanic upwelling off Northwest Africa (station 11, Figure 5A). The magnitude of this vertical migration was also related to the zooplankton biomass, showing higher migrant biomass in both stations 8 and 11 (Table 1). Variability of zooplankton migrant biomass was considerable, and changed over two orders of magnitude from the oligotrophic to the eutrophic waters.

Micronekton migrant biomass, as also expected, increased from the oligotrophic to the meso- and eutrophic stations in the Guinea Dome, and the upwelling off Northwest Africa (Figure 5A). Large migrant crustaceans increased north of the ITCZ coinciding with the lowest oxygen values in the water column, while fish migrant biomass showed less variability along the transect (Figure 5B). Micronekton biomass changed depending on the capture efficiency (CE) used to convert the catch to biomass (see Material and Methods). Differences between our quite conservative 50\% CE, and the 20\% CE were rather high (see Figure 5A), and illustrate the implications of the criteria used to estimate micronekton biomass. In any case, replicated hauls performed with the Mesopelagos trawl showed quite close values (see station 11 in Figure 5A).

\section{Zooplankton and Micronekton Respiratory Flux}

Zooplankton ETS activity profiles showed higher values in the epipelagic zone as expected from the higher temperature there (Figure 6). An increasing trend was also observed in the mesopelagic zone along the transect as temperature was higher at depth in the northern stations (Table 1). We also found statistically significant higher ETS activities during the day compared to night values in the mesopelagic zone ( $t$-test for independent values, $p<0.001$, Figure 7A). This higher activity was observed coinciding with the expected residence depth of migrants but also related to the oxygen minimum zone (see Hernández-León et al., 2019a).

Micronekton ETS activities were obtained in the epipelagic zone by night and at mesopelagic depths by day for fish (myctophids and bristlemouths) and crustaceans (decapods and euphausiids). Organisms captured by the Mesopelagos trawl sampling the entire water column were also corrected for the average temperature at 200-800 m layer (Table 2 and Figure 7B). 


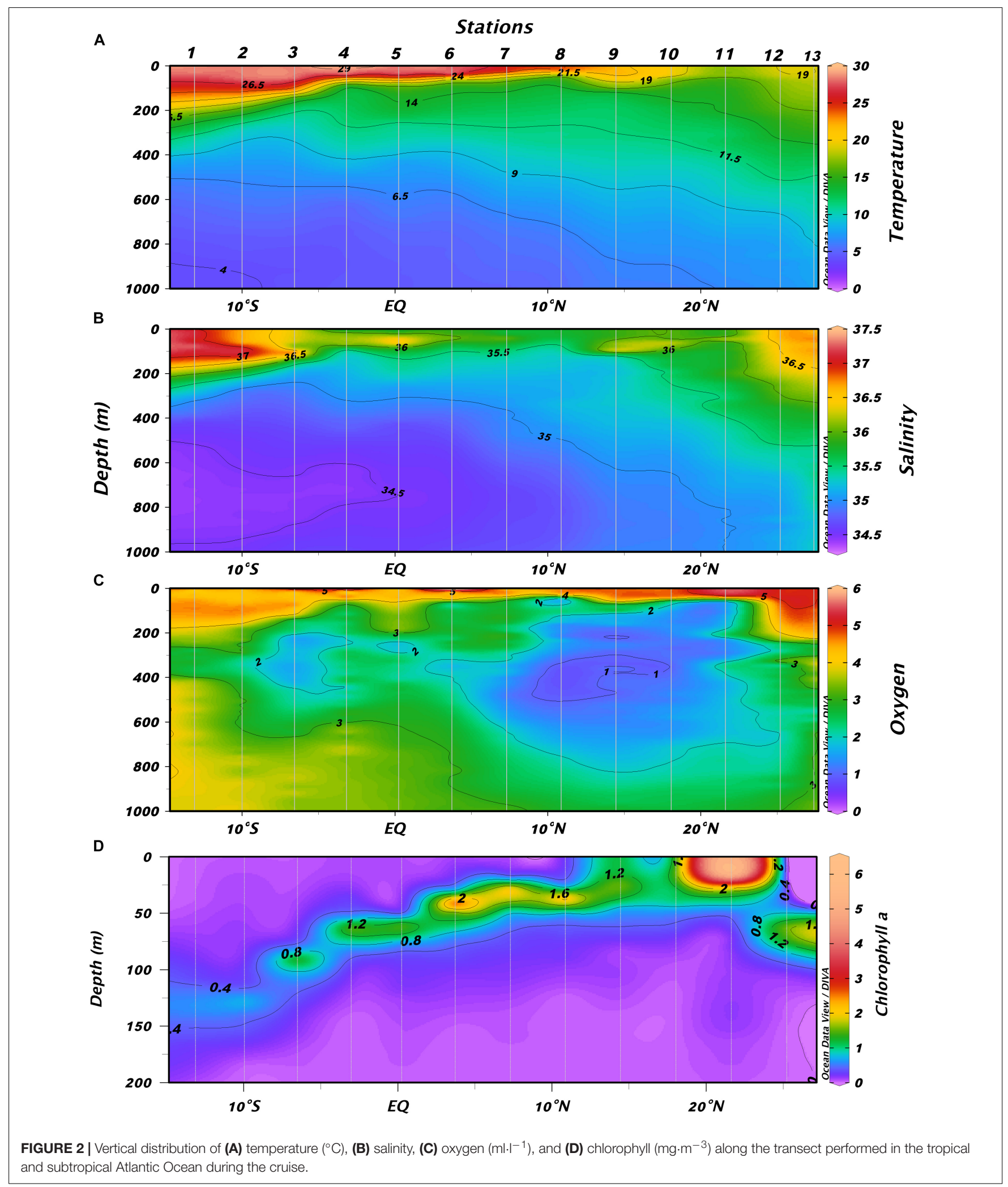

ETS values along the transect were quite variable but, in general, increased north of the ITCZ (Figure 7B). We used all the ETS values from Figure 7B to derive respiration rates for the different groups at the average temperature for the $200-800 \mathrm{~m}$ layer at each station (Table 1). Myctophids showed values in the range $0.18-1.13 \mu \mathrm{lO}_{2} \cdot \mathrm{mg} \mathrm{Dw}^{-1} \cdot \mathrm{h}^{-1}$ (average $0.44 \pm 0.31 \mathrm{SD}$ ), 

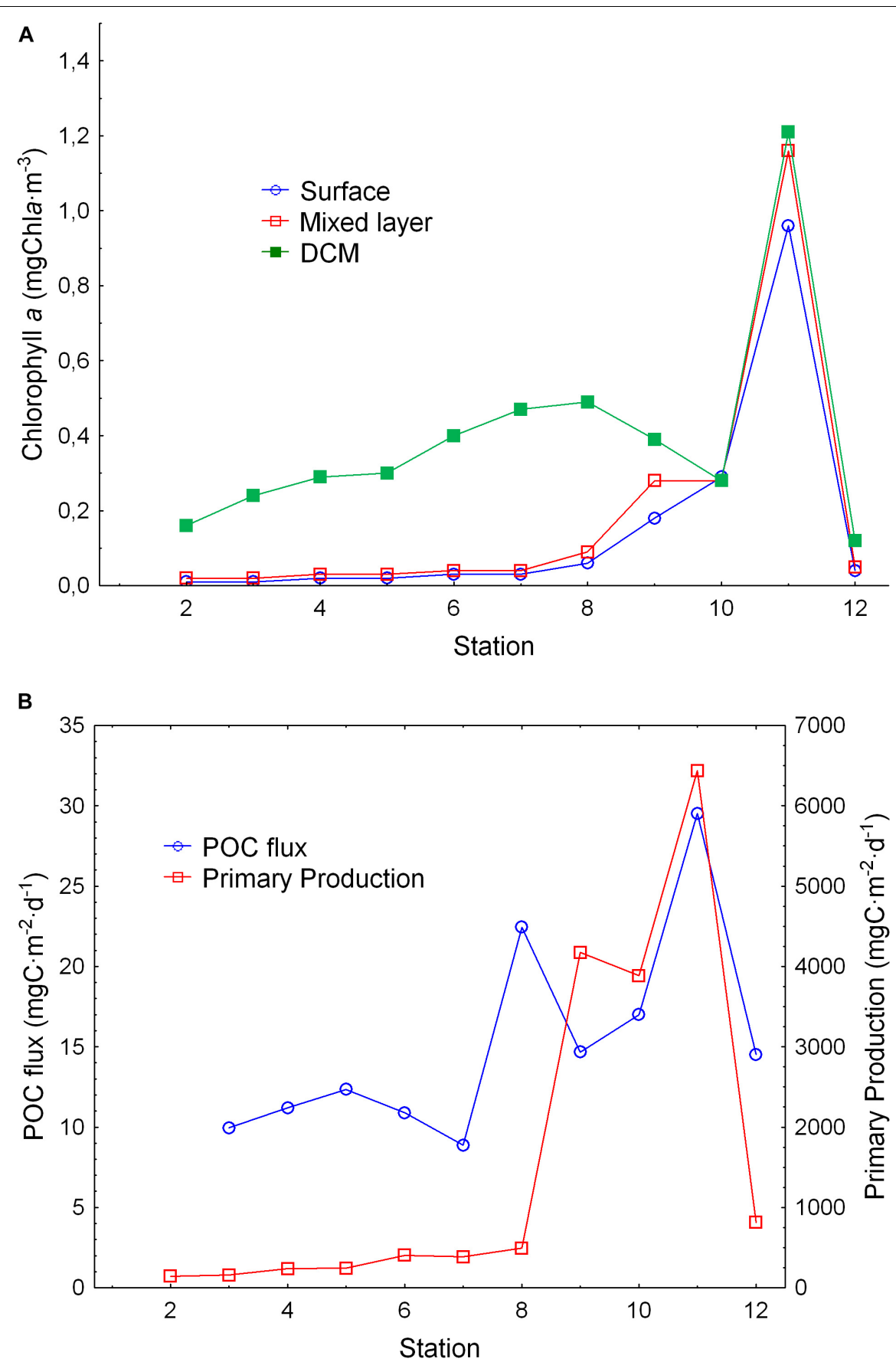

FIGURE 3 | (A) Chlorophyll at the surface (empty dots), mixed layer (empty squares), and at deep chlorophyll maximum (full squares). (B) POC flux (dots) and primary production (squares) obtained from remote sensing (VGPM model) along the transect performed during the cruise.

while respiration in bristlemouths was more variable and in the range $0.03-0.64 \mu \mathrm{lO}_{2} \cdot \mathrm{mg} \mathrm{Dw}^{-1} \cdot \mathrm{h}^{-1}$ (average $0.25 \pm 0.24$ $\mathrm{SD})$. Respiration rates of decapods were in the range 0.03-2.29 $\mu \mathrm{IO}_{2} \cdot \mathrm{mg} \mathrm{Dw}^{-1} \cdot \mathrm{h}^{-1}$ (average $0.66 \pm 0.67 \mathrm{SD}$ ).

Respiratory flux by zooplankton was obtained from the migrant biomass and respiration rates by day averaged for the 200-800 m layer (Table 1). Values were higher in stations showing higher migrant biomass. Respiratory flux was highly correlated to migrant biomass as expected (as respiratory flux is a function of migrant biomass). This regression (Figure 8A) is given in order to compare to other results in the literature. In this sense, our values were highly comparable to previous studies also performed at the large-scale (Figure 8A, HernándezLeón et al., 2019b). The new equation calculated using data from 

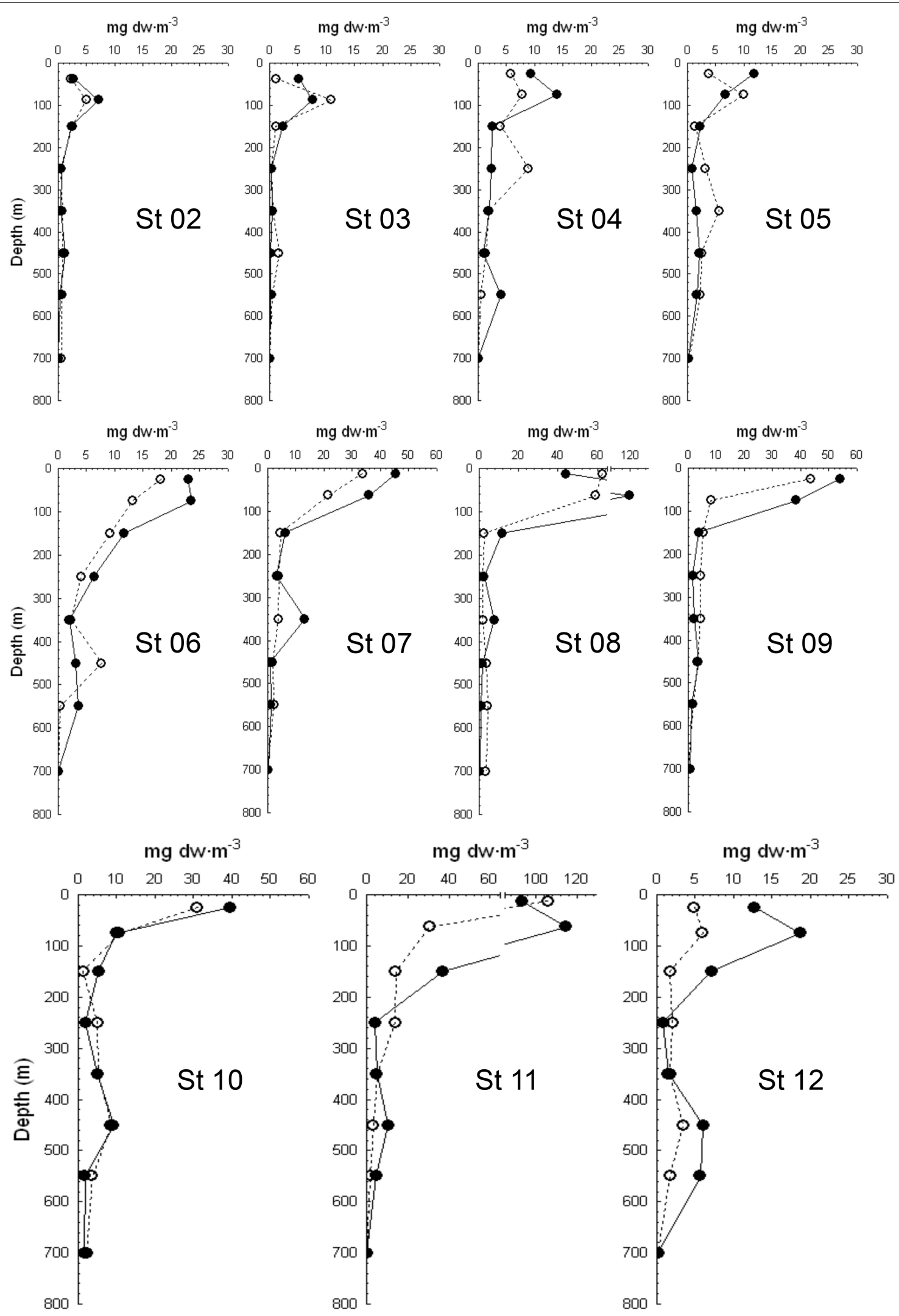

FIGURE 4 | Vertical distribution of zooplankton biomass during day (empty dots) and night (black dots) at the different stations along the Atlantic Ocean transect. 


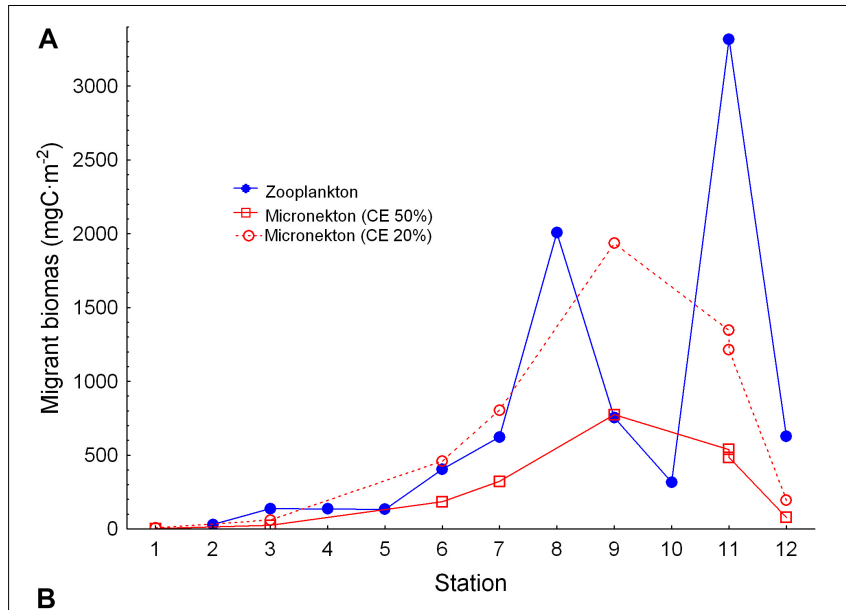

B

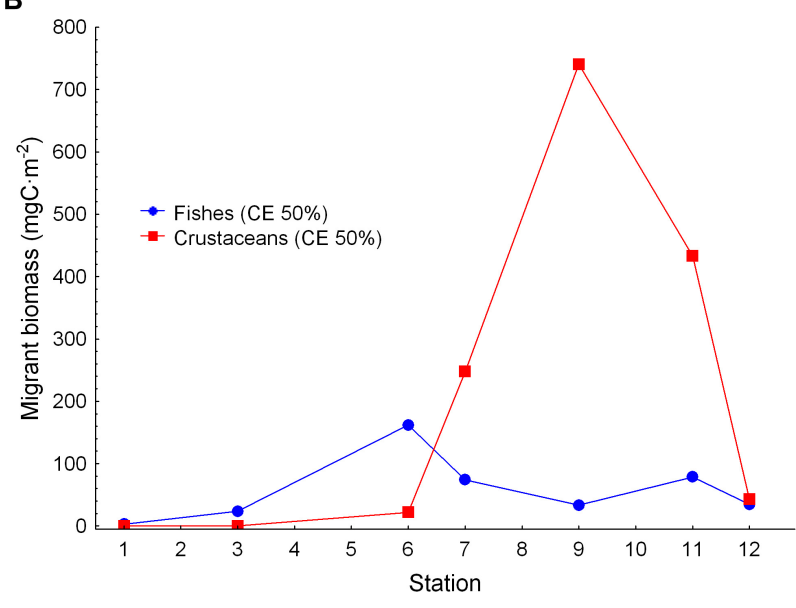

FIGURE 5 | (A) Zooplankton and micronekton migrant biomass (night minus day in the epipelagic zone) along the Atlantic transect. Micronekton migrant biomass was estimated at 20 and $50 \%$ of capture efficiency (see text) and it is depicted here for comparison. (B) Fish and crustacean migrant biomass along the transect.

both studies showed a highly significant correlation $\left(r^{2}=0.866\right.$, $p<0.001, n=20)$. The values from Hernández-León et al. (2019b) were recalculated using the same dry weight/protein ratio as used here and given by Hernández-León et al. (2019a) from a recent review of this ratio for subtropical waters. Respiratory flux by micronekton (myctophids and decapods) using the quite conservative capture efficiency of $50 \%$ was also highly correlated to migrant biomass, and relatively similar to the respiratory flux by zooplankton obtained in this study (Figure 8B).

\section{Total Active Flux}

We found a significant relationship between zooplankton and micronekton total active flux ( $\log _{10}$ Micronekton flux $=-0.670+1.165 \cdot \log _{10}$ Zooplankton flux; $r^{2}=0.756$, $p<0.05, n=6$, see Supplementary Figure S1). So, in order to have a better picture of micronekton active flux and because of the limited set of data for this community (only seven stations), we used this relationship to estimate the total flux of micronekton for the other four stations (stations 4, 5, 8, and 10).
Large values of zooplankton and micronekton flux were observed in the Guinea Dome (station 8) and in the upwelling zone off Northwest Africa (Figure 9A). Comparing POC flux and total active flux by both zooplankton and micronekton (Figure 9B and Table 3) we observed relatively constant values of POC flux along the transect with some larger values in the Guinea Dome and the oceanic upwelling off Cape Blanc, but also quite high values of total active flux coinciding with both upwelling areas. This is a striking result as active flux in both productive areas was observed between three and fivefold the POC flux (Figure 9B). These differences are clearly observed comparing the proportion of the different fluxes (zooplankton, micronekton, and POC flux) along the tropical and subtropical transect (Figure 10). As observed, POC flux is the most important component in very oligotrophic systems such as the SECC, but it sharply decreased as productivity increased northward. In the mesoand/or eutrophic zones of the Guinea Dome and the oceanic upwelling off Northwest Africa, POC flux was only 16-25\% of total flux considered in this study (Figure 10).

Finally, despite the low number of both joint zooplankton and micronekton flux assessments, we found significant relationships between primary production obtained from remote sensing and total active flux (Figure 11A). Similarly, we observed primary production and POC flux also significantly correlated (Figure 11B). Total active flux was more variable than POC flux as noted from the different slopes, indicating a more important response of zooplankton and micronekton to an increase in productivity.

\section{DISCUSSION}

Zooplankton and micronekton vertical distribution, migrant biomass, and respiratory flux concurrently with passive flux were studied in a sharp gradient of productivity along a transect in the tropical and subtropical Atlantic Ocean. This is to our knowledge the first attempt to estimate these fluxes at the basin scale, and one of the very few assessments of both zooplankton and micronekton active flux in the ocean. We observed respiratory flux closely related to the migrant biomass as expected (Figure 8). This relationship in zooplankton was in accordance with a previous study, also at the large-scale in the Atlantic Ocean in a sharp gradient from the upwelling zone off Northwest Africa to central gyre waters (Hernández-León et al., 2019b). Respiratory flux in micronekton was also closely related to migrant biomass. However, the absolute value of this flux is still pending on the capture efficiency of the trawl used for sampling. This is an important shortcoming of our active flux assessment and clearly identifies a research subject for future studies. Besides trawl sampling, the role of new technologies such as optical systems and in situ acoustic systems should be developed to advance this knowledge.

Another feature of our sampling was the important role of decapods in the most productive area, and coinciding with the sharp oxygen minimum zones (OMZs) observed along our transect. This is similar to the results by Vereshchaka et al. (2016) who also found a high biomass of decapods in the tropical 
TABLE 1 | Average temperature and zooplankton migrant biomass, ETS activity, respiration rates, and respiratory flux along the tropical and subtropical Atlantic Ocean.

\begin{tabular}{|c|c|c|c|c|c|c|c|c|c|c|c|c|}
\hline Station & $\begin{array}{c}\text { Average } \\
\text { Temperature } \\
200-800 \mathrm{~m}\left({ }^{\circ} \mathrm{C}\right)\end{array}$ & SD & $\begin{array}{l}\text { Migrant biomass } \\
\left(\mathrm{mgC} \cdot \mathrm{m}^{-2}\right)\end{array}$ & $\begin{array}{c}\text { Average sp. ETS } \\
\text { at } 200-800 \mathrm{~m} \text { by } \\
\text { day }\left(\mu 1 \mathrm{O}_{2} \cdot \mathrm{mg}\right. \\
\left.\operatorname{prot}^{-1} 1 \cdot \mathrm{h}^{-1}\right)\end{array}$ & SD & $\begin{array}{c}\text { Respiration at } \\
\text { depth by day } \\
\left(\mu 1 \mathrm{O}_{2} \cdot \mathrm{mg}\right. \\
\left.\operatorname{prot}^{-1} \cdot \mathrm{h}^{-1}\right)\end{array}$ & $\begin{array}{c}\text { Respiration } \\
\text { atdepth by day } \\
\left(\mu \mid \mathrm{O}_{2} \cdot \mathrm{mg} \cdot \mathrm{dw}^{-1} \cdot \mathrm{h}^{-1}\right)\end{array}$ & $\begin{array}{l}\text { Respiration at } \\
\text { depth by day } \\
\left(d^{-1}\right)\end{array}$ & $\begin{array}{l}\text { Respiratory flux } \\
\left(\mathrm{mgC} \cdot \mathrm{m}^{-2} \cdot \mathrm{d}^{-1}\right)\end{array}$ & $\begin{array}{l}\text { Respiratory flux } \\
\left(\mathrm{mgC} \cdot \mathrm{m}^{-2} \cdot 12 \mathrm{~h}^{-1}\right)(\mathrm{r}\end{array}$ & $\begin{array}{c}\text { POC flux } \\
\mathrm{mgC} \cdot \mathrm{m}^{-2} \cdot \mathrm{d}^{-1} \text { ) }\end{array}$ & $\begin{array}{l}\text { Respiratory } \\
\text { flux/POC (\%) }\end{array}$ \\
\hline 2 & 7.47 & 2.61 & 29.5 & 4.73 & 2.57 & 2.37 & 0.95 & 0.03 & 0.9 & 0.4 & & \\
\hline 3 & 7.23 & 2.05 & 138.1 & 3.26 & 2.39 & 1.63 & 0.65 & 0.02 & 2.8 & 1.4 & 10.0 & 14.1 \\
\hline 4 & 7.73 & 2.62 & 135.9 & 3.36 & 2.09 & 1.68 & 0.67 & 0.02 & 2.9 & 1.4 & 11.2 & 12.8 \\
\hline 5 & 7.99 & 2.42 & 133.2 & 6.79 & 3.47 & 3.39 & 1.36 & 0.04 & 5.7 & 2.8 & 12.4 & 22.9 \\
\hline 6 & 7.76 & 2.22 & 405.3 & 3.64 & 2.83 & 1.82 & 0.73 & 0.02 & 9.2 & 4.6 & 10.9 & 42.4 \\
\hline 7 & 8.71 & 2.10 & 622.2 & 3.90 & 2.64 & 1.95 & 0.78 & 0.02 & 15.2 & 7.6 & 8.9 & 85.6 \\
\hline 8 & 9.00 & 1.94 & 2007.5 & 6.63 & 6.07 & 3.32 & 1.33 & 0.04 & 83.3 & 41.6 & 22.5 & 185.5 \\
\hline 9 & 9.56 & 1.59 & 755.3 & 4.70 & 2.00 & 2.35 & 0.94 & 0.03 & 22.2 & 11.1 & 14.7 & 75.6 \\
\hline 10 & 9.71 & 1.81 & 317.5 & 2.71 & 1.23 & 1.36 & 0.54 & 0.02 & 5.4 & 2.7 & 17.0 & 15.8 \\
\hline 11 & 10.48 & 1.84 & 3316.5 & 3.51 & 1.78 & 1.75 & 0.70 & 0.02 & 72.7 & 36.4 & 29.5 & 123.2 \\
\hline \multirow[t]{2}{*}{12} & 11.54 & 2.43 & 626.4 & 2.72 & 1.47 & 1.36 & 0.55 & 0.02 & 10.7 & 5.3 & 14.5 & 36.7 \\
\hline & & & & & & & & & $\begin{array}{c}\text { Average } \\
\text { SD }\end{array}$ & $\begin{array}{l}10.5 \\
14.5\end{array}$ & $\begin{array}{l}15.1 \\
6.4\end{array}$ & $\begin{array}{l}61.5 \\
56.9\end{array}$ \\
\hline
\end{tabular}

Respiratory flux was estimated for $12 \mathrm{~h}$ of organisms residence at depth during daylight hours. POC flux is also given and compared to the respiratory flux (in \%). SD, standard deviation. 

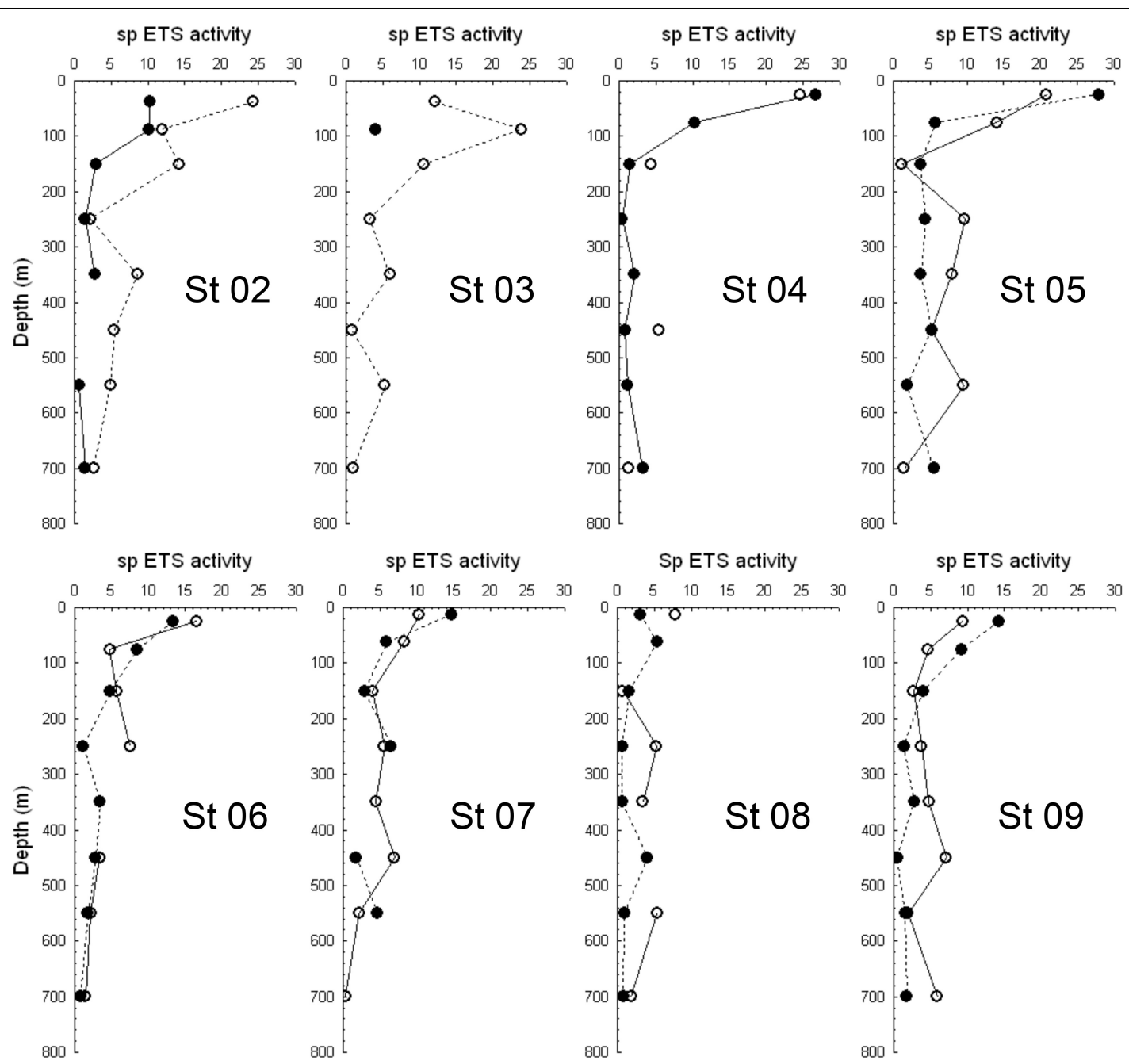

sp ETS activity
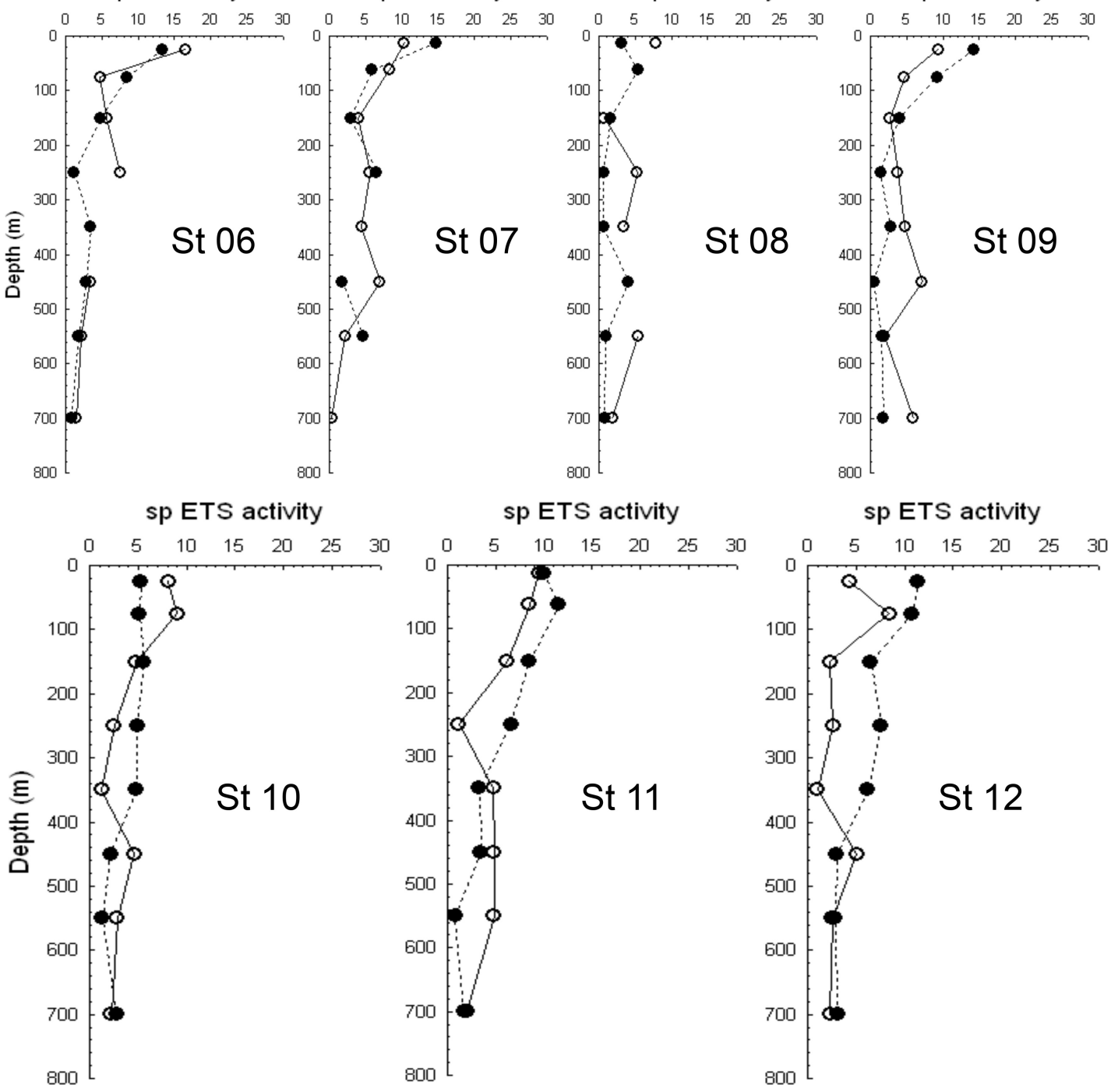

FIGURE 6 | Vertical profiles of zooplankton ETS activity $\left(\right.$ in $\mu \mathrm{IO}_{2} \cdot \mathrm{mg}$ protein ${ }^{-1} \cdot \mathrm{h}^{-1}$ ) along the transect. Empty dots are daylight activity values, while black dots are nighttime ETS activity. 


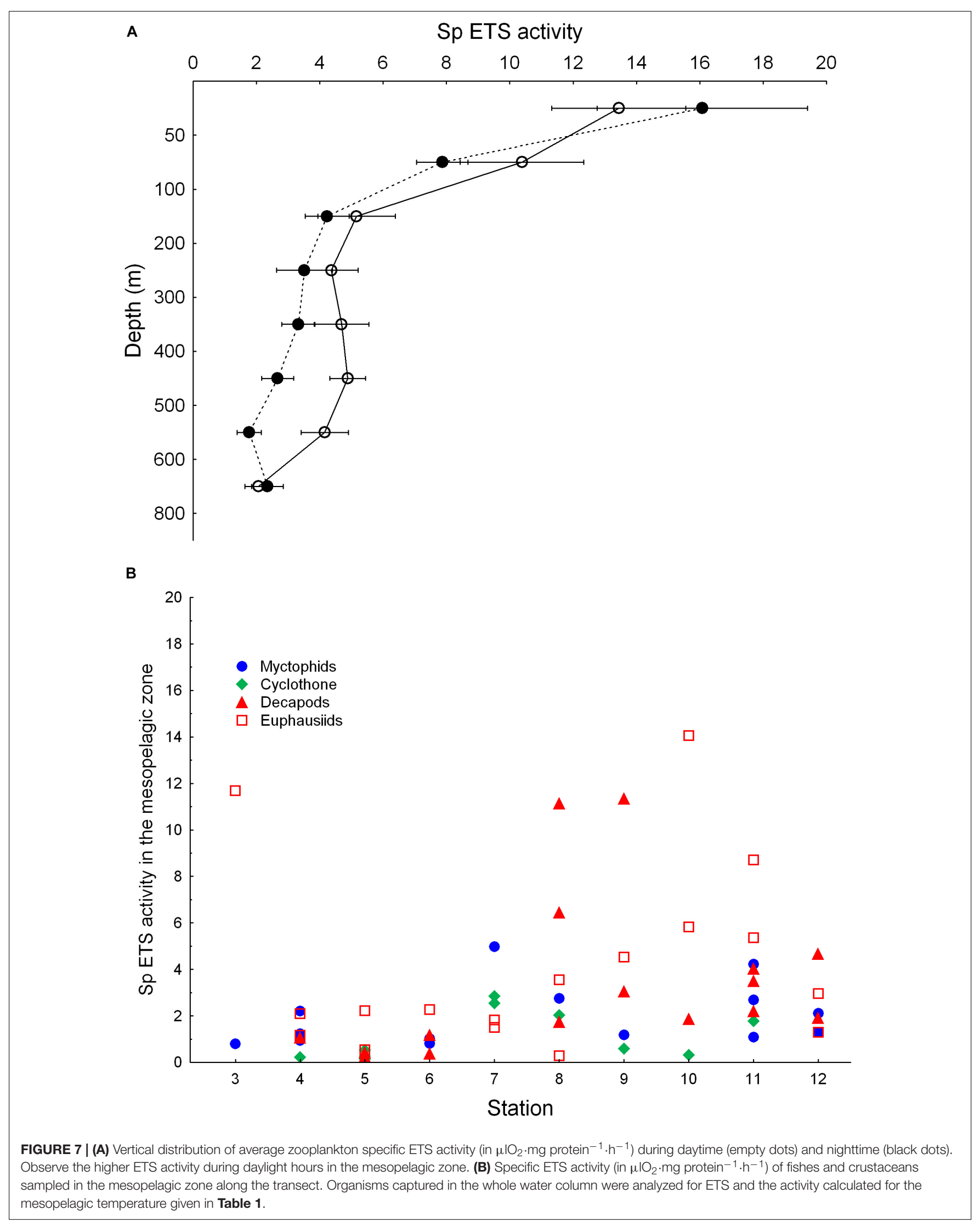


TABLE 2 | Micronekton migrant biomass using 20 and 50\% of capture efficiency for the Mesopelagos trawl and respiration rates, respiratory flux obtained using both capture efficiencies along the tropical and subtropical Atlantic Ocean.

\begin{tabular}{|c|c|c|c|c|c|c|}
\hline Station & $\begin{array}{l}\text { CE } 50 \% \text { Migrant biomass } \\
\text { fishes }\left(\mathrm{mgC} \cdot \mathrm{m}^{-2}\right)\end{array}$ & $\begin{array}{l}\text { CE } 20 \% \text { Migrant } \\
\text { biomass fishes } \\
\left(\mathrm{mgC} \cdot \mathrm{m}^{-2}\right)\end{array}$ & $\begin{array}{l}\text { CE } 50 \% \text { Respiration } \\
\left(\mathrm{mgC} \cdot \mathrm{m}^{-2} \cdot \mathrm{d}^{-1}\right)\end{array}$ & $\begin{array}{c}\text { CE } 20 \% \\
\text { Respiration } \\
\left(\mathrm{mgC} \cdot \mathrm{m}^{-2} \cdot \mathrm{d}^{-1}\right)\end{array}$ & $\begin{array}{c}\text { CE } 50 \% \\
\text { Respiratory flux } \\
\text { fishes } \\
\left(\mathrm{mgC} \cdot \mathrm{m}^{-2} \cdot 12 \mathrm{~h}^{-1}\right)\end{array}$ & $\begin{array}{c}\text { CE } 20 \% \\
\text { Respiratory flux } \\
\text { fishes } \\
\left(\mathrm{mgC} \cdot \mathrm{m}^{-2} \cdot 12 \mathrm{~h}^{-1}\right)\end{array}$ \\
\hline 1 & 3.0 & 7.5 & 0.04 & 0.11 & 0.02 & 0.05 \\
\hline 3 & 23.7 & 59.2 & 0.33 & 0.83 & 0.17 & 0.41 \\
\hline 6 & 161.7 & 404.4 & 2.26 & 5.66 & 1.13 & 2.83 \\
\hline 7 & 74.1 & 185.3 & 1.04 & 2.59 & 0.52 & 1.30 \\
\hline 9 & 33.5 & 83.8 & 0.47 & 1.17 & 0.23 & 0.59 \\
\hline 11 & 106.3 & 265.7 & 1.49 & 3.72 & 0.74 & 1.86 \\
\hline 11 & 51.3 & 128.3 & 0.72 & 1.80 & 0.36 & 0.90 \\
\hline 12 & 34.6 & 86.5 & 0.48 & 1.21 & 0.24 & 0.61 \\
\hline Mean & 61.0 & 152.6 & & & 0.43 & 1.07 \\
\hline \multirow[t]{2}{*}{ SD } & 51.7 & 129.1 & & & 0.36 & 0.90 \\
\hline & $\begin{array}{l}\text { CE } 50 \% \text { Migrant biomass } \\
\text { crustaceans }\left(\mathrm{mgC} \cdot \mathrm{m}^{-2}\right)\end{array}$ & $\begin{array}{l}\text { CE } 20 \% \text { Migrant } \\
\text { biomass } \\
\text { crustaceans } \\
\left(\mathrm{mgC} \cdot \mathrm{m}^{-2}\right)\end{array}$ & $\begin{array}{l}\text { CE } 50 \% \text { Respiration } \\
\left(\mathrm{mgC} \cdot \mathrm{m}^{-2} \cdot \mathrm{d}^{-1}\right)\end{array}$ & $\begin{array}{c}\text { CE } 20 \% \\
\text { Respiration } \\
\left(\mathrm{mgC} \cdot \mathrm{m}^{-2} \cdot \mathrm{d}^{-1}\right)\end{array}$ & $\begin{array}{c}\text { CE } 50 \% \\
\text { Respiratory flux } \\
\text { crustaceans } \\
\left(\mathrm{mgC} \cdot \mathrm{m}^{-2} \cdot 12 \mathrm{~h}^{-1}\right)\end{array}$ & $\begin{array}{c}\text { CE } 20 \% \\
\text { Respiratory flux } \\
\text { crustaceans } \\
\left(\mathrm{mgC} \cdot \mathrm{m}^{-2} \cdot 12 \mathrm{~h}^{-1}\right)\end{array}$ \\
\hline 1 & 0.00 & 0.00 & 0.00 & 0.00 & 0.00 & 0.00 \\
\hline 3 & 0.00 & 0.00 & 0.00 & 0.00 & 0.00 & 0.00 \\
\hline 6 & 21.99 & 54.97 & 0.46 & 1.15 & 0.23 & 0.58 \\
\hline 7 & 247.69 & 619.24 & 5.20 & 13.00 & 2.60 & 6.50 \\
\hline 9 & 740.72 & 1851.81 & 15.56 & 38.89 & 7.78 & 19.44 \\
\hline 11 & 431.80 & 1079.49 & 9.07 & 22.67 & 4.53 & 11.33 \\
\hline 11 & 433.78 & 1084.46 & 9.11 & 22.77 & 4.55 & 11.39 \\
\hline 12 & 43.14 & 107.84 & 0.91 & 2.26 & 0.45 & 1.13 \\
\hline Mean & 239.9 & 599.7 & & & 2.52 & 6.30 \\
\hline \multirow[t]{2}{*}{$\mathrm{SD}$} & 274.3 & 685.7 & & & 2.88 & 7.20 \\
\hline & $\begin{array}{l}\text { CE } 50 \% \text { Migrant biomass } \\
\text { fish }+ \text { crustaceans } \\
\left(\mathrm{mgC} \cdot \mathrm{m}^{-2}\right)\end{array}$ & $\begin{array}{c}\text { CE } 20 \% \text { Migrant } \\
\text { biomass } \\
\text { fish }+ \text { crustaceans } \\
\left(\mathrm{mgC} \cdot \mathrm{m}^{-2}\right)\end{array}$ & $\begin{array}{c}\text { CE } 50 \% \text { Respiratory flux } \\
\text { fish }+ \text { crustaceans } \\
\left(\mathrm{mgC} \cdot \mathrm{m}^{-2} \cdot 12 \mathrm{~h}^{-1}\right)\end{array}$ & $\begin{array}{c}\text { CE } 20 \% \\
\text { Respiratory flux } \\
\text { fish + crustaceans } \\
\left(\mathrm{mgC} \cdot \mathrm{m}^{-2} \cdot 12 \mathrm{~h}^{-1}\right)\end{array}$ & $\begin{array}{c}\text { CE } 50 \% \\
\text { Respiratory } \\
\text { flux/POC (\%) }\end{array}$ & $\begin{array}{c}\text { CE } 20 \% \\
\text { Respiratory } \\
\text { flux/POC (\%) }\end{array}$ \\
\hline 1 & 3.0 & 7.5 & 0.02 & 0.05 & & \\
\hline 3 & 23.7 & 59.2 & 0.17 & 0.41 & 1.7 & 4.2 \\
\hline 6 & 183.7 & 459.3 & 1.36 & 3.41 & 12.5 & 31.3 \\
\hline 7 & 321.8 & 804.5 & 3.12 & 7.80 & 35.2 & 87.9 \\
\hline 9 & 774.2 & 1935.6 & 8.01 & 20.03 & 54.6 & 136.4 \\
\hline 11 & 538.1 & 1345.2 & 5.28 & 13.19 & 17.9 & 44.7 \\
\hline 11 & 485.1 & 1212.8 & 4.91 & 12.28 & 16.6 & 41.6 \\
\hline 12 & 77.7 & 194.3 & 0.70 & 1.74 & 4.8 & 12.0 \\
\hline Mean & 300.9 & 752.3 & 2.95 & 7.37 & 20.5 & 51.2 \\
\hline SD & 278.7 & 696.8 & 2.90 & 7.25 & 18.5 & 46.4 \\
\hline
\end{tabular}

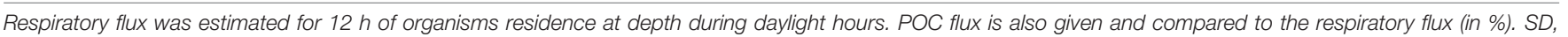
standard deviation.

zone, in a similar transect in the Atlantic Ocean. Previous papers emphasized the importance of mesopelagic fishes in relation to decapods and large euphausiids in the micronekton flux (Ariza et al., 2015). This was the case in our transect for the oligotrophic and equatorial zones. However, decapods were abundant in the most productive zones (Figure 5B). Important values of the respiratory flux was also observed for these organisms by Schukat et al. (2013) in upwelling zones, thus, their role in active flux could be considerable. We also observed decapod abundance to match not only the most productive areas but also the OMZs. Many migrant decapods are known to be adapted to survive at quite low oxygen concentrations (Childress, 1975). These organisms are able to regulate their respiration to live aerobically in these OMZs. Thus, this observation could explain at least in part, the large biomass of decapods in the area related to the OMZs in this Atlantic transect. 


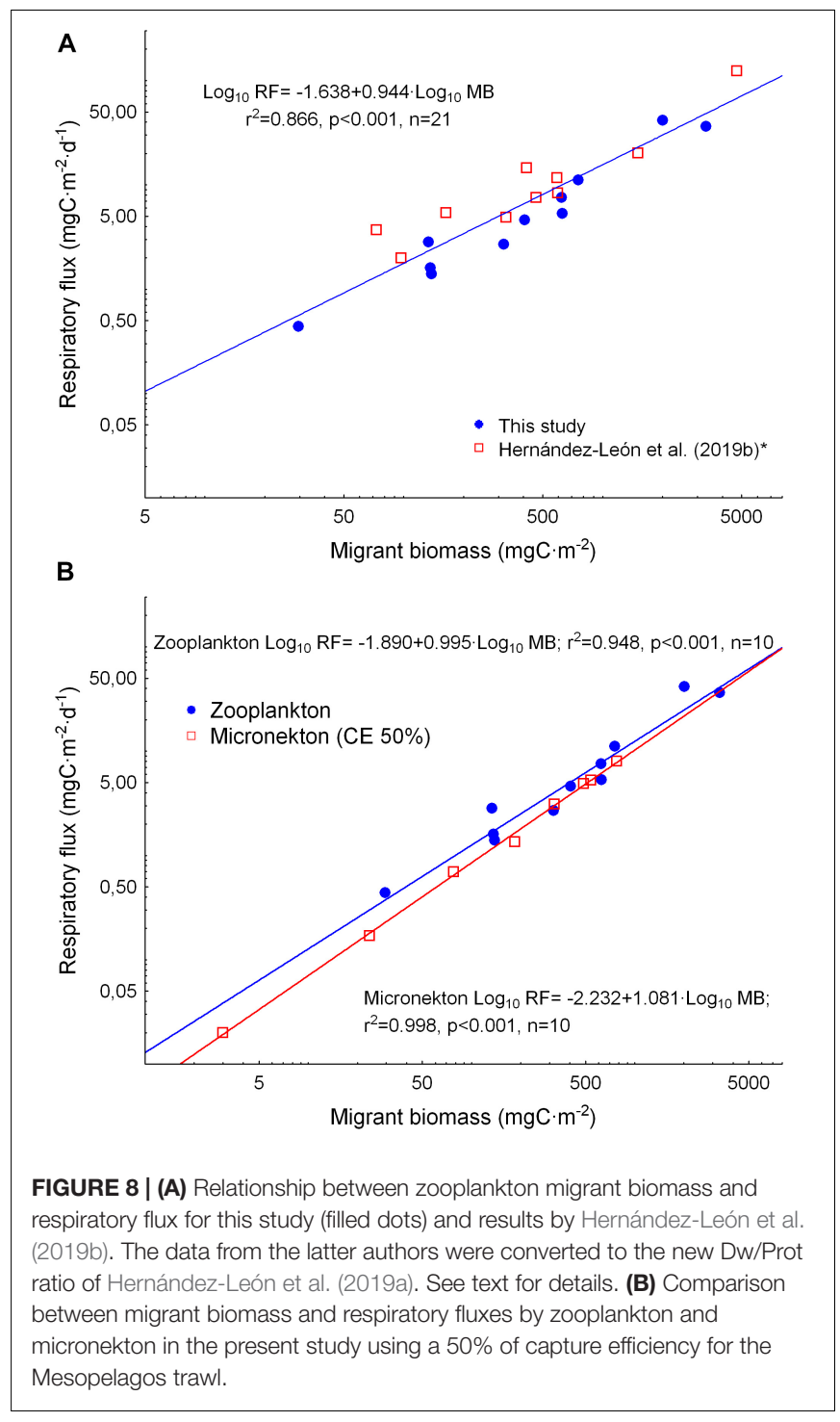

In any case, our estimates of zooplankton and micronekton active flux were obtained using quite conservative values. Firstly, zooplankton biomass is always considered undersampled due to avoidance of nets by organisms, mainly large zooplankton which are the bulk of migrant biomass. The undersampling in micronekton was considered above (see section "Material and Methods") but here we used a 50\% catch efficiency which is quite conservative. At least, there is no study showing values of the capture efficiency larger than the one used here. In order to keep our assessments conservative in both communities, ETS activity were converted to respiration rates (R) using a R/ETS ratio of 0.5 . This ratio is also quite conservative as recently found for migrant copepods (Hernández-León et al., 2019a). These authors observed no differences in mesopelagic respiration between the R/ETS ratio of 1 , and the values obtained using the equations of Ikeda (1985) and Ikeda (2014) derived from temperature, body weight, and depth. A R/ETS ratio between 0.5 and 1 during the residence time of migrant organisms at depth

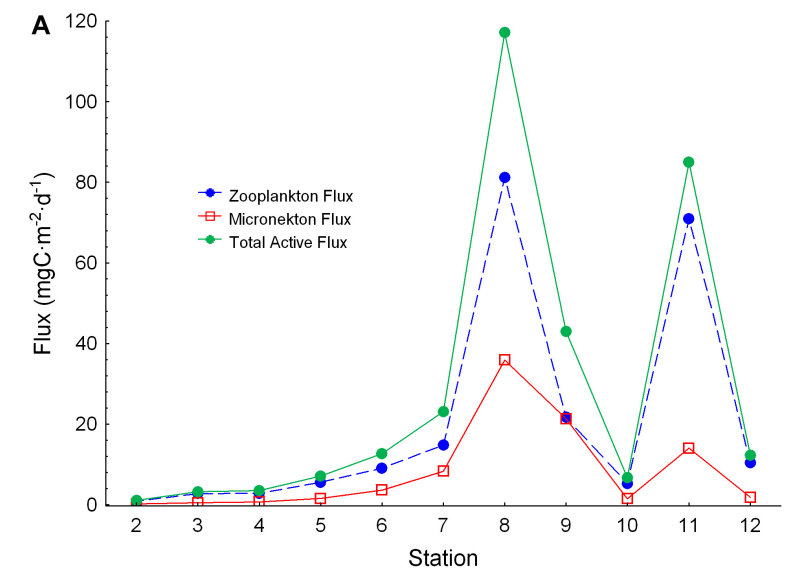

B

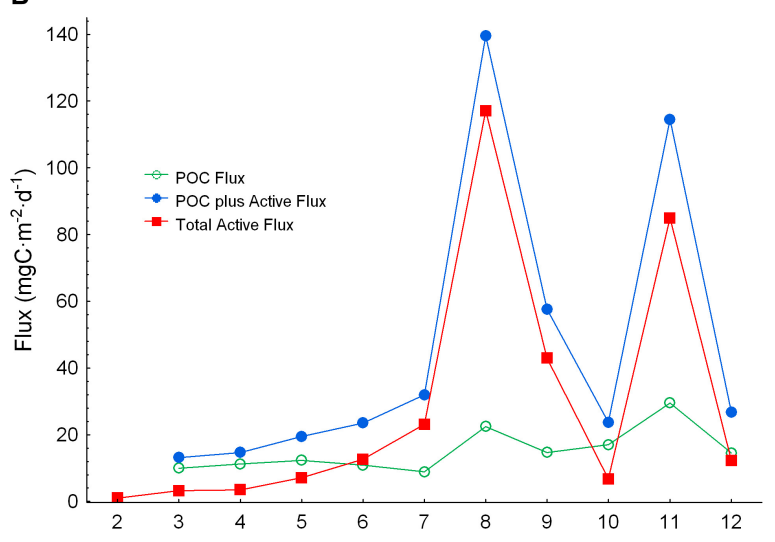

FIGURE 9 | (A) Active flux by zooplankton and micronekton using a 50\% capture efficiency for the Mesopelagos trawl, and total active flux by both communities. (B) Comparison between total active flux and POC flux, and estimated total flux. Micronekton active flux for stations 4, 5, 8, and 10 were estimated from zooplankton active flux (see text).

approaches better to respiration rates in nature as observed by Hernández-León et al. (2019a). However, we kept the lower value in order to maintain a conservative estimate of active flux. This criterion was also used to convert ETS activity to respiration rates in micronekton. Thus, our assessment of respiratory flux in both communities should be considered as a base line for this downward carbon transport in the ocean due to vertical migrants. In any case, ETS activities obtained were compared to previous studies (Ariza et al., 2015) and ranged closely, indicating that values were comparable in magnitude.

Higher active flux is expected in productive areas because organisms with a low turnover such as large zooplankton and micronekton could develop into high biomass because of the large and constant food supply. However, POC flux did not increase in a similar proportion in those productive areas. We found respiratory to POC flux ratios to increase toward the most productive area in the north, and quite high values in the Guinea Dome and the oceanic upwelling off Cape Blanc (>100\%, Table 1). Similarly, Hernández-León et al. (2019b) found 2.5fold higher POC flux in the most oligotrophic environment (a 
TABLE 3 | Total active flux estimated as the sum of respiratory flux and estimated mortality, excretory, and gut flux performed by zooplankton and micronekton in comparison to primary production obtained by remote sensing (VGPM model) and POC flux obtained using sediment traps.

\begin{tabular}{|c|c|c|c|c|c|c|c|}
\hline Station & $\begin{array}{c}\text { Primary } \\
\text { production } \\
\left(\mathrm{mgC} \cdot \mathrm{m}^{-2} \cdot \mathrm{d}^{-1}\right)\end{array}$ & SD & $\begin{array}{l}\text { Zooplankton total } \\
\text { active flux } \\
\left(\mathrm{mgC} \cdot \mathrm{m}^{-2} \cdot 12 \mathrm{~h}^{-1}\right)\end{array}$ & $\begin{array}{c}\text { CE } 50 \% \text { Micronekton } \\
\text { total active flux } \\
\left(\mathrm{mgC} \cdot \mathrm{m}^{-2} \cdot 12 \mathrm{~h}^{-1}\right)\end{array}$ & $\begin{array}{c}\text { CE } 20 \% \text { Micronekton } \\
\text { total active flux } \\
\left(\mathrm{mgC} \cdot \mathrm{m}^{-2} \cdot 12 \mathrm{~h}^{-1}\right)\end{array}$ & $\begin{array}{c}\text { CE } 50 \% \text { Total } \\
\text { active flux/POC } \\
(\%)\end{array}$ & $\begin{array}{c}\text { CE } 20 \% \text { Total } \\
\text { active flux/POC } \\
(\%)\end{array}$ \\
\hline 1 & & & & 0.1 & 0.1 & - & - \\
\hline 2 & 144 & 10 & 0.9 & - & - & - & - \\
\hline 3 & 158 & 11 & 2.7 & 0.4 & 1.1 & 4.4 & 11.1 \\
\hline 4 & 236 & 13 & 2.8 & - & - & - & - \\
\hline 5 & 243 & 23 & 5.5 & - & - & - & - \\
\hline 6 & 405 & 50 & 9.0 & 3.6 & 9.1 & 33.3 & 83.2 \\
\hline 7 & 384 & 17 & 14.8 & 8.3 & 20.7 & 93.6 & 233.9 \\
\hline 8 & 492 & 11 & 81.2 & - & - & - & - \\
\hline 9 & 4175 & 578 & 21.6 & 21.3 & 53.3 & 145.2 & 362.9 \\
\hline 10 & 3887 & 2383 & 5.2 & - & - & - & - \\
\hline 11 & 6438 & 4409 & 70.9 & 14.0 & 35.1 & 47.5 & 118.9 \\
\hline 11 & - & - & - & 13.1 & 32.7 & 44.3 & 110.7 \\
\hline 12 & 814 & 90 & 10.4 & 1.8 & 4.6 & 12.7 & 31.8 \\
\hline Mean & & & 20.5 & 7.8 & 19.6 & 54.4 & 136.1 \\
\hline SD & & & 27.6 & 7.7 & 19.3 & 49.3 & 123.3 \\
\hline
\end{tabular}

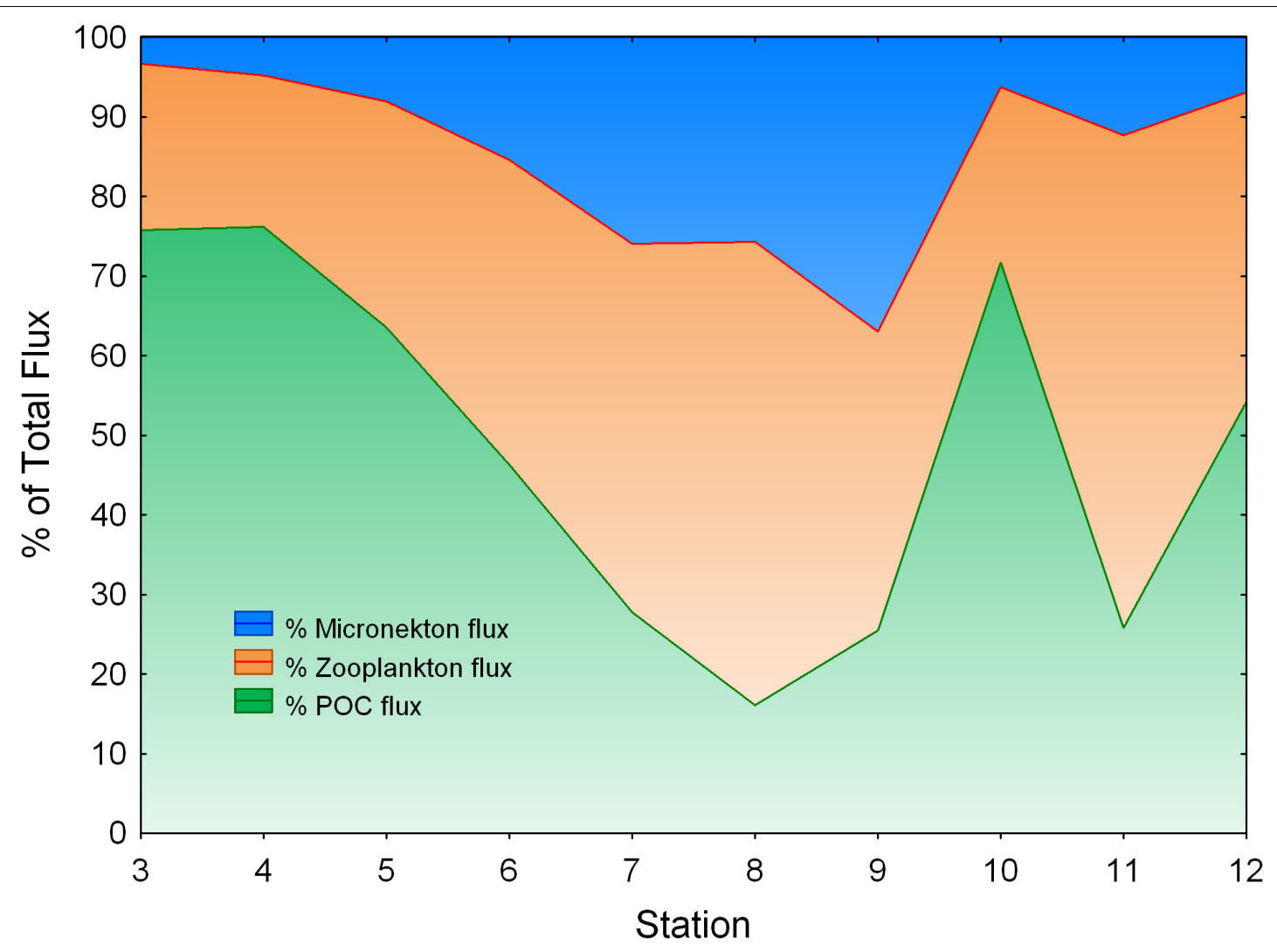

FIGURE 10 | Percentage of POC flux (lower), zooplankton active flux (middle), and micronekton flux using a 50\% capture efficiency for the Mesopelagos trawl (upper). Observe the decreasing percentage of POC flux as productivity increases. Micronekton active flux for stations $4,5,8$, and 10 were estimated from zooplankton active flux (see text).

longitudinal transect south of the Canary Islands) compared to the most productive zone sampled (a longitudinal transect departing from Cape Blanc along the Cape Vert Frontal Zone).
Zooplankton respiratory flux was, on average, less than $10 \%$ of POC flux in the oligotrophic transect while it was higher than $40 \%$ in the most productive. They explained this relationship 


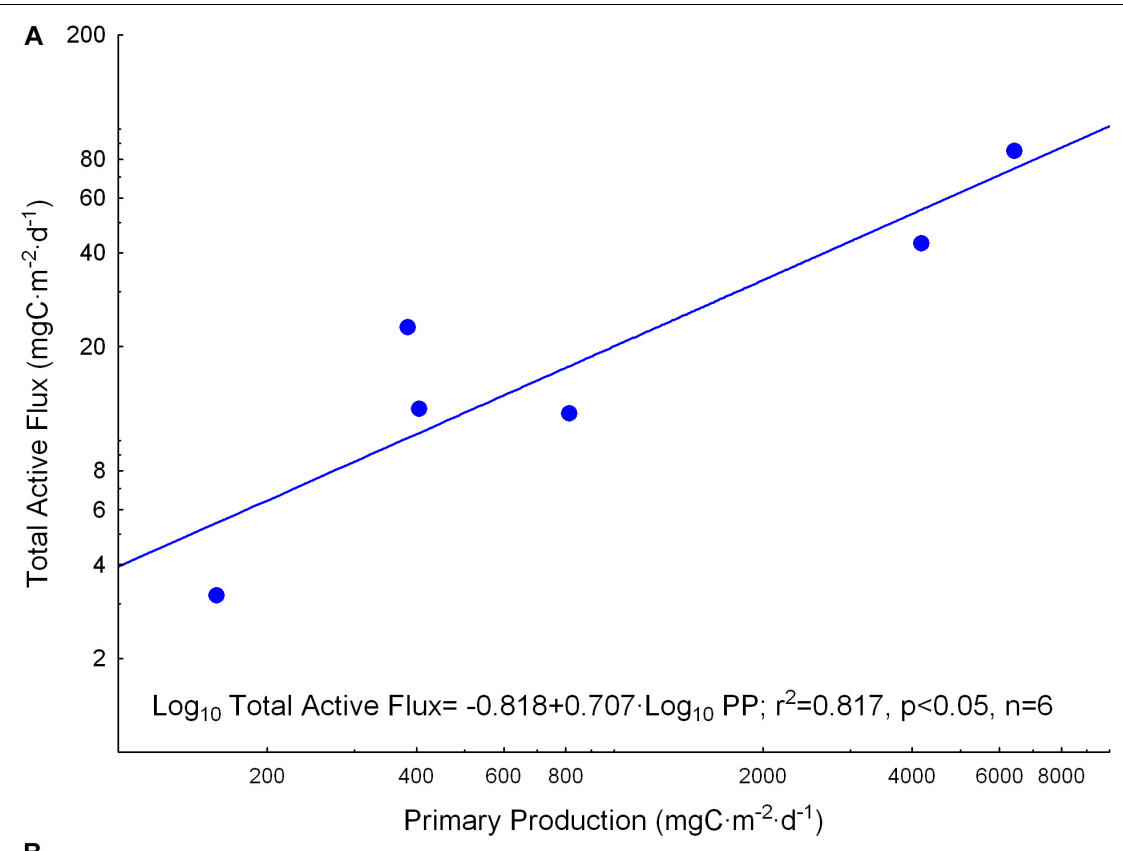

B

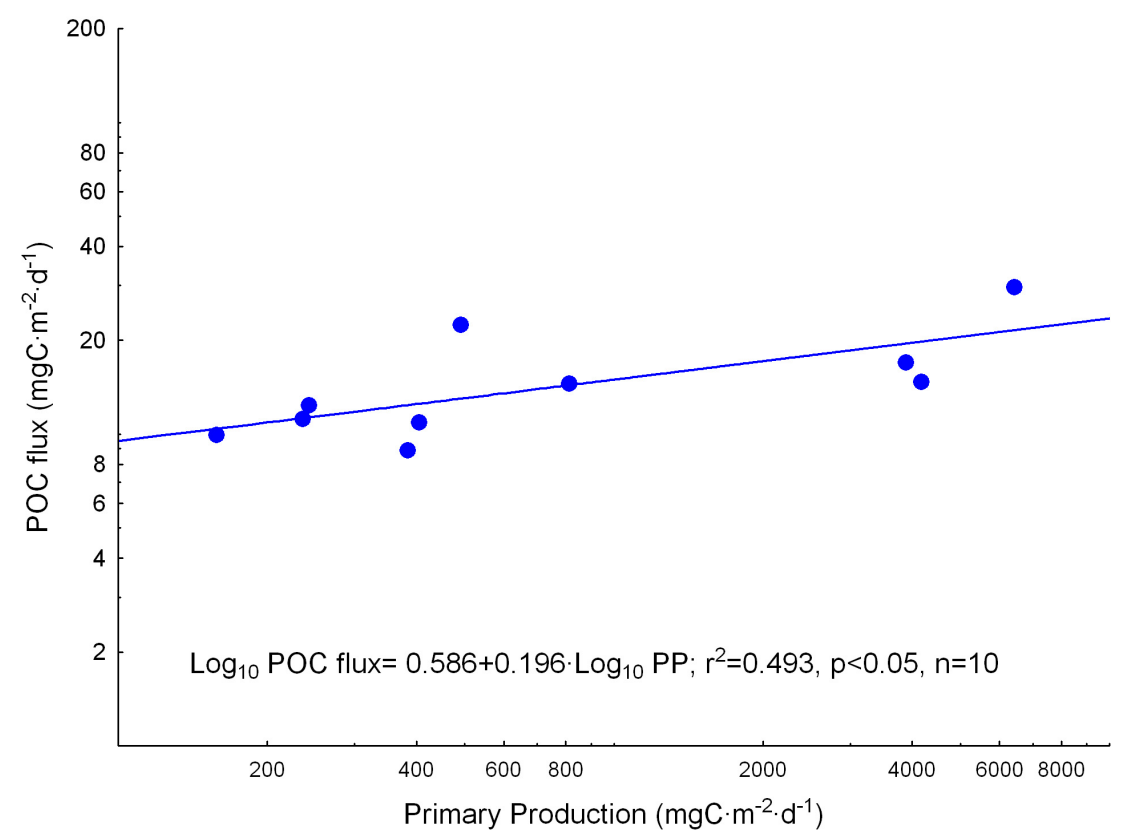

FIGURE 11 | Relationships between primary production obtained from remote sensing (VGPM model) and (A) total active flux by zooplankton and micronekton, and (B) particle organic carbon (POC) flux measured using drifting sediment traps at $150 \mathrm{~m}$ depth.

between POC and active fluxes as (1) the processing of particles by zooplankton, shaping the downward flux of particles, (2) the intense lateral transport of particles from the upwelling zone to the open ocean, or (3) both. The first explanation is supported by the zooplankton processing and fragmentation of particles through feeding in the epipelagic zone (Le Moigne et al., 2016; Cavan et al., 2017). However, in areas affected by upwelling, the offshore transport of particulate organic matter is known to be considerable (Lovecchio et al., 2017). This transport to the open ocean promotes lower sedimentation because of the lateral transport of particles, and longer residence times in the epipelagic zone, therefore, favoring the zooplankton and prokaryotes processing of particles in the upper layers. Our results in the oceanic upwelling off Cape Blanc could be affected by this offshore transport. In the Guinea Dome, lateral transport should also be important as we sampled in the area affected by the westward motion of the cyclonic structure, probably transporting the highly productive coastal upwelled waters. In this sense, 
Armengol et al. (2019) showed a filament-like structure affecting station 8 in their surface map of primary production during the same oceanographic cruise (see their Figure 5). Whatever the effect of zooplankton or lateral advection, in areas of high primary production large organisms are favored (e.g., Frost, 1974), as constant energy fuels their longer lives, therefore, promoting a large biomass.

The large values of total active flux observed in areas of persistent productivity such as the mid-ocean upwelling, the Guinea Dome, or the oceanic upwelling off Cape Blanc suggests that the oceanic carbon pump is quite variable and active flux is not simply a constant value of POC flux as it is suggested in recent models (14-18\%, Aumont et al., 2018; Archibald et al., 2019). In these studies as well as in the recent review by Steinberg and Landry (2017), active flux showed values lower than about $30 \mathrm{mgC} \cdot \mathrm{m}^{-2} \cdot \mathrm{d}^{-1}$ which is coincident with the values obtained during most of our Atlantic transect (Figure 9B). Thus, their models should reflect the general picture as about $70 \%$ of the ocean is oligotrophic. However, the magnitude of the biological carbon pump is quite variable as observed here in a sharp gradient of productivity along the tropical and subtropical Atlantic Ocean (Figure 10). Although most of the ocean is oligotrophic, mesoscale activity is widespread and it is known that there is an increase in productivity in these mesoscale structures maintained over long periods (McGillicuddy et al., 1998; Mahadevan, 2016). This increase in active flux by zooplankton related to mesoscale structures was observed long ago by Yebra et al. (2005) in an anticyclonic eddy shed by the Canary Islands. Recently, Yebra et al. (2018) also showed large active flux values by zooplankton in the Alboran gyre in the Mediterranean Sea. Thus, the development of zooplankton and micronekton related to mesoscale eddies, rings, or oceanic frontal zones could promote sharp increments in the downward carbon transport due to active flux. Moreover, sustained natural (e.g., dust) or artificial (e.g., iron) fertilized areas should also promote an increase of low turnover communities such as zooplankton and micronekton vertical migrants in the long run, promoting vertical flux beyond the immediate effect of an increase in productivity in shallow waters.

In this sense, the large values of active flux observed in the Guinea Dome deserves some attention. Recently, Stukel et al. (2018) found a dominant role of vertical migrants in the biological pump in the Costa Rica Dome, an analogous physical structure to the open-ocean upwelling of the Guinea Dome. Using a different approach, they observed active transport by the pelagic fauna as the dominant vertical transport mechanism, and only $11-17 \%$ of export was due to other mechanisms (physical mixing and phytoplankton sinking). This high active flux in the Costa Rica Dome is similar to our results in the Guinea Dome, as we also observed a low proportion of POC flux compared to the zooplankton and micronekton downward transport. Stukel et al. (2018) explained the energy transfer from the characteristic small phytoplankton (cyanobacteria) of these physical structures to zooplankton due to the role of protists as an important intermediate trophic level in these upwelling systems. Armengol et al. (2019) during our cruise observed the Guinea Dome dominated by small cells (picoeukaryotes and Synechococcus), not showing a high microzooplankton biomass compared to other productive stations, but displaying relatively high autotroph growth rates at the surface layer. In any case, oceanic domes are physical structures promoting an important role of the pelagic fauna in the biological pump. Whatever the mechanism, continuous fueling of primary production, the role of protists, or both, the study of active flux in these oceanic structures seems of interest in order to understand the functioning of pelagic systems.

Finally, despite the limited data set of both zooplankton and micronekton active flux in the present study, we found primary production obtained from remote sensing quite well correlated to total active flux by both communities (Figure 11A). POC flux was also significantly correlated to primary production in our study (Figure 11B), but showed a lower slope, therefore, varying less than total active flux. This lower slope should be related to lateral advection and the processing of particles by zooplankton as discussed above. Thus, the role of zooplankton and micronekton in driving the biological pump seems of paramount importance. Further research is required to verify the former equation as it could allow the estimation of total active flux from remote sensing.

In summary, we observed a striking response of the biological pump in areas of persistent high primary production through the growth of zooplankton and micronekton vertical migrant populations. Their metabolism could promote an increase in the carbon flux of, at least, twofold the POC flux, promoting quite high active flux values (Figure 9). As observed, there is a small response of POC flux to gradients in productivity compared to the effect of the migrant fauna. So, in areas of high productivity most of the vertical flux is suggested to be performed by zooplankton and micronekton (Figure 10). Our assessment of active flux was quite conservative as we used a high capture efficiency for the micronekton trawl (50\%), and a quite conservative estimation of respiration rates (R/ETS ratio of 0.5, see Hernández-León et al., 2019a). Thus, our results considering both zooplankton and micronekton communities open new avenues to evaluate the export of carbon in the ocean and the functioning of the pelagic realm. These results confirm the importance of the mesopelagic-migrant pump in driving the biological pump (Boyd et al., 2019).

\section{DATA AVAILABILITY}

The datasets generated for this study are available on request to the corresponding author.

\section{AUTHOR CONTRIBUTIONS}

SH-L designed and promoted this study, acted as cruise leader, and measured ETS activity. MO, CL-P, VT, and JG-G sampled, measured biomass, and classified micronekton organisms. MFP sampled and classified the zooplankton organisms. AB measured the passive flux. AC designed the multi-sampler and deployed the Mesopelagos net. All authors contributed to the interpretation and writing of the manuscript as well as discussion of results and comments on the manuscript. 


\section{FUNDING}

This work was supported by projects "Migrants and Active Flux in the Atlantic Ocean" (MAFIA, CTM2012-39587-C04), and "Biomass and Active Flux in the Bathypelagic Zone" (Bathypelagic, CTM2016-78853-R) from the Spanish Ministry of Economy and Competitiveness.

\section{ACKNOWLEDGMENTS}

We would like to thank the two reviewers for their efforts to amend the manuscript. We are also indebted to the crew and other scientists on board the research vessel "Hespérides," and

\section{REFERENCES}

Angel, M. V. (1989). “Does mesopelagic biology affect the vertical flux?," in Productivity of the Ocean: Present and Past, eds W. H. Berger, V. S. Smetacek, and G. Wefer (New York, NY: Wiley), 155-173.

Archibald, K. M., Siegel, D. A., and Doney, S. C. (2019). Modeling the impact of zooplankton diel vertical migration on the carbon export flux of the biological pump. Glob. Biogeochem. Cycles 33, 181-199. doi: 10.1029/2018GB0 05983

Ariza, A., Garijo, J. C., Landeira, J. M., Bordes, F., and Hernández-León, S. (2015). Migrant biomass and respiratory carbon flux by zooplankton and micronekton in the subtropical northeast Atlantic Ocean (Canary Islands). Prog. Oceanogr. 134, 330-342. doi: 10.1016/j.pocean.2015. 03.003

Armengol, L., Calbet, A., Franchy, G., Rodríguez-Santos, A., and Hernández-León, S. (2019). Planktonic food web structure and trophic transfer efficiency along a productivity gradient in the tropical and subtropical Atlantic Ocean. Sci. Rep. 9:2044. doi: 10.1038/s41598-019-38507-9

Aumont, O., Maury, O., Lefort, S., and Bopp, L. (2018). Evaluating the potential impacts of the diurnal vertical migration by marine organisms on marine biogeochemistry. Glob. Biogeochem. Cycles 32, 1622-1643. doi: 10.1029/ 2018GB005886

Bailey, T. G., Youngbluth, M. J., and Owen, G. P. (1995). Chemical composition and metabolic rates of gelatinous zooplankton from midwater and benthic boundary layer environments off Cape Hatteras, North Carolina, USA. Mar. Ecol. Prog. Ser. 122, 121-134. doi: 10.3354/meps12 2121

Behrenfeld, M. J., and Falkowski, P. G. (1997). Photosynthetic rates derived from satellite-based chlorophyll concentration. Limnol. Oceanogr. 42, 1-20. doi: 10.4319/lo.1997.42.1.0001

Boyd, P. W., Claustre, H., Levy, M., Siegel, D. A., and Weber, T. (2019). Multifaceted particle pumps drive carbon sequestration in the ocean. Nature 568, 327-336. doi: 10.1038/s41586-019-1098-2

Brett, J. R., and Groves, T. D. D. (1979). Physiological energetics. Fish Physiol. 8, 280-352.

Buesseler, K. O., Antia, A. N., Chen, M., Fowler, S. W., Gardner, W. D., Gustafsson, O., et al. (2007). An assessment of the use of sediment traps for estimating upper ocean particle fluxes. J. Mar. Res. 65, 345-416. doi: 10.1357/ 002224007781567621

Castonguay, M., and McCleave, J. D. (1987). Vertical distributions, diel and ontogenetic vertical migrations and net avoidance of leptocephali of Anguilla and other common species in the Sargasso Sea. J. Plankton Res. 9, 195-214. doi: 10.1093/plankt/9.1.195

Cavan, E. L., Henson, S. A., Belcher, A., and Sanders, R. (2017). Role of zooplankton in determining the efficiency of the biological carbon pump. Biogeosciences 14 , 177-186. doi: 10.5194/bg-14-177-2017

Childress, J. J. (1975). The respiratory rates of midwater crustaceans as a function of depth of occurrence and relation to the oxygen minimum layer off southern California. Comp. Biochem. Physiol. Part A Physiol. 50, 787-799. doi: 10.1016/ 0300-9629(75)90146-2 the technicians of the "Unidad de Tecnología Marina" (UTM) for their support and help during the cruise. This article is a publication of the Unidad Océano y Clima, Universidad de Las Palmas de Gran Canaria, a R\&D\&i CSIC-associated unit.

\section{SUPPLEMENTARY MATERIAL}

The Supplementary Material for this article can be found online at: https://www.frontiersin.org/articles/10.3389/fmars. 2019.00535/full\#supplementary-material

FIGURE S1 | Relationship between total active flux of zooplankton and micronekton.

Childress, J. J., and Nygaard, M. H. (1973). The chemical composition of midwater fishes as a function of depth of occurence off southern California. Deep Sea Res. 20, 1093-1109. doi: 10.1016/0011-7471(73)90023-5

Dam, H. G., and Peterson, W. T. (1988). The effect of temperature on the gut clearance rate constant of planktonic copepods. J. Exp. Mar. Biol. Ecol. 123, 1-14. doi: 10.1016/0022-0981(88)90105-0

Dam, H. G., and Peterson, W. T. (1993). Seasonal contrasts in the diel vertical distribution, feeding behavior, and grazing impact of the copepod Temora longicornis in Long Island Sound. J. Mar. Res. 51, 561-594. doi: 10.1357/ 0022240933223972

Davison, P. C. (2011). The Export of Carbon Mediated by Mesopelagic Fishes in the Northeast Pacific Ocean. PhD Thesis, University of California, San Diego, CA.

Davison, P. C., Checkley, D. M. Jr., Koslow, J. A., and Barlow, J. (2013). Carbon export mediated by mesopelagic fishes in the northeast Pacific Ocean. Prog. Oceanogr. 116, 14-30. doi: 10.1016/j.pocean.2013.05.013

Frost, B. W. (1974). "Feeding processes at lower trophic levels in pelagic communities," in The Biology of Oceanic Pacific, ed. C. B. Miller (Corvallis, OR: Oregon State University Press), 59-77.

Gjøsaeter, J. (1984). Mesopelagic fish, a large potential resource in the Arabian Sea. Deep Sea Res. 31, 1019-1035. doi: 10.1016/0198-0149(84)90054-2

Gómez, M., Torres, S., and Hernández-León, S. (1996). Modification of the electron transport system (ETS) method for routine measurements of respiratory rates of zooplankton. South Afr. J. Mar. Sci. 17, 15-20. doi: 10.2989/ 025776196784158446

Grosjean, P., and Denis, K. (2007). Zoo/PhytoImage Version 1.2-0. User's Manual. Available at: http://www.sciviews.org/zooimage (accessed September 9, 2011).

Guidi, L., Legendre, L., Reygondeau, G., Uitz, J., Stemmann, L., and Henson, S. A. (2015). A new look at ocean carbon remineralization for estimating deepwater sequestration. Glob. Biogeochem. Cycles 29, 1044-1059. doi: 10.1002/ $2014 \mathrm{gb} 005063$

Hernández-León, S., and Gómez, M. (1996). Factors affecting the respiration/ETS ratio in marine zooplankton. J. Plankton Res. 18, 239-255. doi: 10.1093/plankt/ 18.2.239

Hernández-León, S., and Montero, I. (2006). Zooplankton biomass estimated from digitalized images in Antarctic waters: a calibration exercise. J. Geophys. Res. Oceans 111:C05s03. doi: 10.1029/2005JC002887

Hernández-León, S., Calles, S., and Fernández de Puelles, M. L. (2019a). The estimation of metabolism in the mesopelagic zone: disentangling deep-sea respiration. Prog. Oceanogr. 178. doi: 10.1016/j.pocean.2019.10 2163

Hernández-León, S., Putzeys, S., Almeida, C., Bécognée, P., Marrero-Diaz, A., Arístegui, J., et al. (2019b). Carbon export through zooplankton active flux in the Canary current. J. Mar. Syst. 189, 12-21. doi: 10.1016/j.jmarsys.2018. 09.002

Hidaka, K., Kawaguchi, K., Murakami, M., and Takahashi, M. (2001). Downward transport of organic carbon by diel migratory micronekton in the western equatorial Pacific: its quantitative and qualitative importance. Deep Sea Res. I 48, 1923-1939. doi: 10.1016/s0967-0637(01)00003-6

Honjo, S., Manganini, S. J., Krishfield, R. A., and Francois, R. (2008). Particulate organic carbon fluxes to the ocean interior and factors controlling the biological 
pump: a synthesis of global sediment trap programs since 1983. Prog. Oceanogr. 76, 217-285. doi: 10.1016/j.pocean.2007.11.003

Hopkins, T. L., Sutton, T., and Lancraft, T. M. (1996). The trophic structure and predation impact of a low latitude midwater fish assemblage. Prog. Oceanogr. 38, 205-239. doi: 10.1016/s0079-6611(97)00003-7

Hudson, J. M., Steinberg, D. K., Sutton, T. T., Graves, J. E., and Latour, R. J. (2014). Myctophid feeding ecology and carbon transport along the northern Mid-Atlantic Ridge. Deep Sea Res. I 93, 104-116. doi: 10.1016/j.dsr.2014.07.002

Ikeda, T. (1985). Metabolic rates of epipelagic marine zooplankton as a function of body mass and temperature. Mar. Biol. 85, 1-11. doi: 10.1007/bf00396409

Ikeda, T. (2014). Respiration and ammonia excretion by marine metazooplankton taxa: synthesis toward a global-bathymetric model. Mar. Biol. 161, 2753-2766. doi: $10.1007 / \mathrm{s} 00227-014-2540-5$

Ikeda, T., and Motoda, S. (1978). Estimated zooplankton production and their ammonia excretion in the Kuroshio and adjacent seas. Fish. Bull. 76, 357-367.

Jónasdóttir, S. H., Visser, A. W., Richardson, K., and Heath, M. R. (2015). Seasonal copepod lipid pump promotes carbon sequestration in the deep North Atlantic. Proc. Natl. Acad. Sci. U.S.A. 112, 12122-12126. doi: 10.1073/pnas.1512110112

Kaartvedt, S., Staby, A., and Aksnes, D. L. (2012). Efficient trawl avoidance by mesopelagic fishes causes large underestimation of their biomass. Mar. Ecol. Prog. Ser. 456, 1-6. doi: 10.3354/meps09785

Kenner, R. A., and Ahmed, S. I. (1975). Measurements of electron transport activities in marine phytoplankton. Mar. Biol. 33, 119-127. doi: 10.1007/ bf00390716

Kloser, R. J., Ryan, T. E., Young, J. W., and Lewis, M. E. (2009). Acoustic observations of micronekton fish on the scale of an ocean basin: potential and challenges. ICES J. Mar. Sci. 66, 998-1006. doi: 10.1093/icesjms/fsp077

Knauer, G. A., Martin, J. H., and Bruland, K. W. (1979). Fluxes of particulate carbon, nitrogen, and phosphorus in the upper water column of the northeast Pacific. Deep Sea Res. I 26, 97-108. doi: 10.1016/0198-0149(79)90 089-x

Koslow, J. A., Kloser, R. J., and Williams, A. (1997). Pelagic biomass and community structure over the mid-continental slope off southeastern Australia based upon acoustic and midwater trawl sampling. Mar. Ecol. Prog. Ser. 146, 21-35. doi: 10.3354/meps 146021

Le Borgne, R., and Rodier, M. (1997). Net zooplankton and the biological pump: a comparison between the oligotrophic and mesotrophic equatorial Pacific. Deep Sea Res. II 44, 2003-2023. doi: 10.1016/s0967-0645(97)00034-9

Le Moigne, F. A., Henson, S. A., Cavan, E., Georges, C., Pabortsava, K., Achterberg, E. P., et al. (2016). What causes the inverse relationship between primary production and export efficiency in the Southern Ocean? Geophys. Res. Lett. 43, 4457-4466. doi: 10.1002/2016gl068480

Lehette, P., and Hernández-León, S. (2009). Zooplankton biomass estimation from digitized images: a comparison between subtropical and Antarctic organisms. Limnol. Oceanogr. Methods 7, 304-308. doi: 10.4319/lom.2009.7.304

Lindsay, D. J. (2003). Carbon and nitrogen contents of mesopelagic organisms: results from Sagami Bay, Japan. JAMSTEC J. Deep Sea Res. 22, 1-13.

Longhurst, A. R., Bedo, A. W., Harrison, W. G., Head, E. J. H., and Sameoto, D. D. (1990). Vertical flux of respiratory carbon by oceanic diel migrant biota. Deep Sea Res. I 37, 685-694. doi: 10.1016/0198-0149(90)90098-g

Lovecchio, E., Gruber, N., Münnich, M., and Lachkar, Z. (2017). On the long-range offshore transport of organic carbon from the Canary Upwelling System to the open North Atlantic. Biogeosciences 14, 3337-3369. doi: 10.5194/bg-14-33372017

Lowry, O. H., Rosebrough, N. J., Farr, A. L., and Randall, R. J. (1951). Protein measurement with the Folin phenol reagent. J. Biol. Chem. 193, 265-275.

Mahadevan, A. (2016). The impact of submesoscale physics on primary productivity of plankton. Annu. Rev. Mar. Sci. 8, 161-184. doi: 10.1146/ annurev-marine-010814-015912

May, J. L., and Blaber, S. J. M. (1989). Benthic and pelagic fish biomass of the upper continental slope off eastern Tasmania. Mar. Biol. 101, 11-25. doi: 10.1007/ bf00393474

McGillicuddy, D. J. Jr., Robinson, A. R., Siegel, D. A., Jannasch, H. W., Johnson, R., Dickey, T. D., et al. (1998). Influence of mesoscale eddies on new production in the Sargasso Sea. Nature 394, 263-266. doi: 10.1038/28367

Meillat, M. (2012). Essais du chalut mésopélagos pour le programme MYCTO 3DMAP de l'IRD, à bord du Marion Dufresne. IFREMER Rapport de mission Marion Dufresne. R.INT.RBE/STH/LTH 2012-2015.
Olivar, M. P., Bode, A., López-Pérez, C., Hulley, P. A., and Hernández-León, S. (2018a). Trophic position of lanternfishes (Pisces: Myctophidae) of the tropical and equatorial Atlantic estimated using stable isotopes. ICES J. Mar. Sci. 76, 649-661. doi: 10.1093/icesjms/fsx243

Olivar, M. P., Contreras, T., Hulley, P. A., Emelianov, M., López, C., Tuset, V., et al. (2018b). Variation in the diel vertical distributions of larvae and transforming stages of oceanic fishes across the tropical and equatorial Atlantic. Prog. Oceanogr. 160, 83-100. doi: 10.1016/j.pocean.2017.12.005

Olivar, M. P., Hulley, P. A., Castellón, A., Emelianov, M., López, C., Tuset, V. M., et al. (2017). Mesopelagic fishes across the tropical and equatorial Atlantic: biogeographical and vertical patterns. Prog. Oceanogr. 151, 116-137. doi: 10. 1016/j.pocean.2016.12.001

Omori, M., and Ikeda, T. (1984). Methods in Marine Zooplankton Ecology. New York, NY: John Wiley and Sons, 332.

Oozeki, Y., Hu, F., Kubota, H., Sugisaki, H., and Kimura, R. (2004). Newly designed quantitative frame trawl for sampling larval and juvenile pelagic fish. Fish. Sci. 70, 223-232. doi: 10.1111/j.1444-2906.2003.00795.x

Owens, T. G., and King, F. D. (1975). The measurement of respiratory electron transport system activity in marine zooplankton. Mar. Biol. 30, 27-36. doi: $10.1007 / \mathrm{bf} 00393750$

Packard, T. T. (1971). The measurement of respiratory electron transport activity in marine phytoplankton. J. Mar. Res. 29, 235-244.

Packard, T. T., Devol, A. H., and King, F. D. (1975). The effect of temperature on the respiratory electron transport system in marine plankton. Deep Sea Res. I 22, 237-249. doi: 10.1016/0011-7471(75)90029-7

Pakhomov, E. A., Podeswa, Y., Hunt, B. P., and Kwong, L. E. (2018). Vertical distribution and active carbon transport by pelagic decapods in the North Pacific Subtropical Gyre. ICES J. Mar. Sci. 76, 702-717. doi: 10.1093/icesjms/ fsy134

Rutter, W. J. (1967). "Methods in developmental biology," in Methods in Developmental Biology, eds H. F. Wilt and N. K. Wessels (London: Academic Press), 671-684.

Schlitzer, R. (2016). Ocean Data View. Available at: http://odv.awi.de

Schukat, A., Bode, M., Auel, H., Carballo, R., Martin, B., Koppelmann, R., et al. (2013). Pelagic decapods in the northern Benguela upwelling system: distribution, ecophysiology and contribution to active carbon flux. Deep Sea Res. I 75, 146-156. doi: 10.1016/j.dsr.2013.02.003

Steinberg, D. K., Carlson, C. A., Bates, N. R., Goldthwait, S. A., Madin, L. P., and Michaels, A. F. (2000). Zooplankton vertical migration and the active transport of dissolved organic and inorganic carbon in the Sargasso Sea. Deep Sea Res. I 47, 137-158. doi: 10.1016/s0967-0637(99)00052-7

Steinberg, D. K., and Landry, M. R. (2017). Zooplankton and the ocean carbon cycle. Annu. Rev. Mar. Sci. 9, 413-444. doi: 10.1146/annurev-marine-010814015924

Strickland, J. D., and Parsons, T. R. (1972). A practical handbook of seawater analysis. Fish. Res. Board Canada 167, 1-281.

Stukel, M. R., Décima, M., Landry, M. R., and Selph, K. E. (2018). Nitrogen and isotope flows through the Costa Rica Dome upwelling ecosystem: the crucial mesozooplankton role in export flux. Glob. Biogeochem. Cycles 32, 1815-1832. doi: 10.1029/2018gb005968

UNESCO (1994). Protocols for the Joint Global Ocean Flux Study (JGOFS) Core Measurements. Manuals and Guides, Vol. 29. Paris: UNESCO, 170.

Vereshchaka, A. L., Abyzova, G., Lunina, A. A., Musaeva, E., and Sutton, T. T. (2016). A novel approach reveals high zooplankton standing stock deep in the sea. Biogeosciences 13, 6261-6271. doi: 10.5194/bg-13-6261-2016

Wiebe, P. H., Burt, K. H., Boyd, S. H., and Morton, A. W. (1976). A multiple opening/closing net and environmental sensing system for sampling zooplankton. J. Mar. Res. 34, 313-326.

Wilson, R. W., Millero, F. J., Taylor, J. R., Walsh, P. J., Christensen, V., Jennings, S., et al. (2009). Contribution of fish to the marine inorganic carbon cycle. Science 323, 359-362. doi: $10.1126 /$ science. 1157972

Yasuma, H., and Yamamura, O. (2010). "Second micronekton inter-calibration experiment, MIE-2. Comparison between acoustic estimates," in Report of the Advisory Panel on Micronekton Sampling Intercalibration Experiment, eds E. Pakhomov and O. Yamamura (Sidney, BC: PICES), 51-56.

Yebra, L., Almeida, C., and Hernández-León, S. (2005). Vertical distribution of zooplankton and active flux across an anticyclonic eddy in the Canary Island waters. Deep Sea Res. I 52, 69-83. doi: 10.1016/j.dsr.2004.08.010 
Yebra, L., Herrera, I., Mercado, J. M., Cortés, D., Gómez-Jakobsen, F., Alonso, A., et al. (2018). Zooplankton production and carbon export flux in the western Alboran Sea gyre (SW Mediterranean). Prog. Oceanogr. 167, 64-77. doi: 10. 1016/j.pocean.2018.07.009

Yentsch, C. S., and Menzel, D. W. (1963). A method for the determination of phytoplanktonic chlorophyll and phaeophytin by fluorescence. Deep Sea Res. I 10, 221-231. doi: 10.1016/0011-7471(63) 90358-9

Zhang, X., and Dam, H. G. (1997). Downward export of carbon by diel migrant mesozooplankton in the central equatorial Pacific. Deep Sea Res. II 44, 2191-2220.
Conflict of Interest Statement: The authors declare that the research was conducted in the absence of any commercial or financial relationships that could be construed as a potential conflict of interest.

Copyright (c) 2019 Hernández-León, Olivar, Fernández de Puelles, Bode, Castellón, López-Pérez, Tuset and González-Gordillo. This is an open-access article distributed under the terms of the Creative Commons Attribution License (CC BY). The use, distribution or reproduction in other forums is permitted, provided the original author(s) and the copyright owner(s) are credited and that the original publication in this journal is cited, in accordance with accepted academic practice. No use, distribution or reproduction is permitted which does not comply with these terms. 